\title{
Spillover and Drivers of Uncertainty among Oil and Commodity Markets
}

\author{
Muhammad Abubakr Naeem $1,2,3, * \mathbb{C}$, Saqib Farid ${ }^{4}$, Safwan Mohd Nor $5,6, * \mathbb{C}$ \\ and Syed Jawad Hussain Shahzad 7,8,*(D) \\ 1 School of Economics and Finance, Massey University, Palmerston North 4442, New Zealand \\ 2 UCD College of Business, University College Dublin, Belfield, Dublin 4, Ireland \\ 3 Business Administration Department, Faculty of Management Sciences, ILMA University, \\ Karachi 75190, Pakistan \\ 4 School of Business and Economics, University of Management and Technology, Lahore 54770, Pakistan; \\ saqib.farid@umt.edu.pk \\ 5 Faculty of Business, Economics and Social Development, University of Malaysia Terengganu, \\ 21030 Kuala Nerus, Terengganu, Malaysia \\ 6 Victoria Institute of Strategic Economic Studies, Victoria University, Melbourne, VIC 3000, Australia \\ 7 Montpellier Business School, University of Montpellier, Montpellier Research in Management, \\ 34080 Montpellier, France \\ 8 Department of Accounting, Analysis and Audit, South Ural State University, Chelyabinsk 454080, Russia \\ * Correspondence: m.naeem@massey.ac.nz (M.A.N.); safwan@umt.edu.my (S.M.N.); \\ j.syed@montpellier-bs.com (S.J.H.S.)
}

Citation: Naeem, M.A.; Farid, S.; Nor, S.M.; Shahzad, S.J.H. Spillover and Drivers of Uncertainty among Oil and Commodity Markets. Mathematics 2021, 9, 441. https://doi.org/10. 3390/math9040441

Academic Editor: Miltiadis Chalikias

Received: 25 January 2021

Accepted: 18 February 2021

Published: 23 February 2021

Publisher's Note: MDPI stays neutral with regard to jurisdictional claims in published maps and institutional affiliations.

Copyright: (c) 2021 by the authors. Licensee MDPI, Basel, Switzerland. This article is an open access article distributed under the terms and conditions of the Creative Commons Attribution (CC BY) license (https:// creativecommons.org/licenses/by/ $4.0 /)$.

\begin{abstract}
The paper aims to examine the spillover of uncertainty among commodity markets using Diebold-Yilmaz approach based on forecast error variance decomposition. Next, causal impact of global factors as drivers of uncertainty transmission between oil and other commodity markets is analyzed. Our analysis suggests that oil is a net transmitter to other commodity uncertainties, and this transmission significantly increased during the global financial crisis of 2008-2009. The use of linear and nonlinear causality tests indicates that the global factors have a causal effect on the overall connectedness, and especially on the spillovers from oil to other commodity uncertainties. Further segregation of transmissions between oil to individual commodity markets indicates that stock market implied volatility, risk spread, and economic policy uncertainty are the influential drivers of connectedness among commodity markets.
\end{abstract}

Keywords: uncertainty transmission; commodities; nonlinear causality; global factors

\section{Introduction}

Amidst the financialization of commodities, understanding the dynamics of commodity markets, such as energy, precious metals, industrial metals, and agriculture, has become an important topic for investors, policymakers, and risk managers. This financialization, along with increased integration of global markets, has augmented the transmission between different markets [1-3]. The increased flow of capital between countries and substantial technological development are the key reasons contributing to globalization. Thus, it is essential to understand the extent and nature of linkages among different financial markets [4].

In global financial markets, oil is considered as an important commodity [5]. Despite being an underlying asset, oil is also considered as life support for profuse economies [6]. The focus of researchers is now moved more towards the transmission among commodities, especially with oil markets, after an increase in general trend for investment in commodity markets [7]. Empirical researchers have proposed several possible channels of connectedness between the oil and other commodity markets. Accordingly, an increase in the price of oil leads to inclination in commodity prices [8]. According to Jain and Ghosh [9], 
the exchange rate and inflation shock in countries that rely heavily on oil imports result due to the increase in global oil prices. Thereby, investors prefer to collect precious metals against inflation and currency risk in such a situation to hedge their portfolios. Hooker [10] proposed that due to expansion in economic activities, there is seen an increase in global demand for oil, which enhances the oil prices that result in more usage of precious and industrial metals, say tin and copper.

Furthermore, oil price shocks result in commodity market inflationary pressure. Because of this inflationary pressure, policymakers tighten the monetary policy, thereby increasing the interest rates, which in turn impact the consumer demand for durable goods [11]. Likewise, the increase in global oil prices also leads to an upward trend in metal or commodity prices due to their impact on production and transportation costs [12]. Additionally, oil prices also have an impact on the growth of an economy-a key driver of demand for agricultural commodities [13]. Recent studies suggested a bi-directional causal relation between agricultural commodity prices and global oil prices [14-16]. The increase in oil prices upshot the cost of essential agricultural inputs, which in turn increases the production costs of agricultural products, thus, affecting the cost of oil substitutes, such as bio-fuels [17].

Recently, various studies have analyzed the transmission mechanism between the oil and commodity markets [18-24]. Hammoudeh and Yuan [11] argued that oil prices act as a determinant of univariate volatilities of precious metals (gold, silver, and copper) in the US metals market. According to Huang et al. [25], there is a positive effect of exchange rates and the US dollar on precious metals. Sari et al. [26] find a short-term relationship between precious metals and crude oil in context of developed countries. Diebold et al. [20] find that there is a high connectedness between energy, precious metals, industrial metals, and agricultural commodities.

Along with the increased interest in the transmission dynamics, there has been considerable attention given by researchers to explore the influence of global factors on commodity markets [27-33]. Batten et al. [34] argued that returns are time-varying, that is, risk-adjusted returns were negative during the Asian financial crisis period, whereas the returns were positive during the global financial crisis (GFC) of 2008-2009. Poncela et al. [32] explore the role of uncertainty in determining co-movements among non-energy prices in the short-run. The study finds increased spillovers among raw materials. Prokopczuk et al. [35] find that there is a bidirectional relationship between volatility of the commodity market with financial and economic uncertainty during a recession period.

Despite a multitude of research concerning the impact of global factors on commodities and other financial markets in separate settings, however, the literature is silent on the effect of global factors on the transmission relationship between oil and commodity markets. In order to fulfill this theoretical void, this study aims to investigate the spillover connectedness among commodities. Additionally, the study seeks to examine the impact of global factors in driving uncertainty spillovers between oil and commodity markets.

Owning to the fact that the financialization of commodities has increased both the intra-commodity connectedness and the connectedness of commodities with other financial markets at a global level, one can assume that commodity markets are exposed to the risks associated with stock markets, currency markets, and uncertainty regarding economic policies. Additionally, in light of the recent literature providing evidence of causal impact of economic policy uncertainty on the connectedness across oil and financial markets $[27,28,30]$, this paper contributes to the literature by (i) examining the transmission between oil and other commodity uncertainties using the Diebold and Yilmaz [36] framework, and (ii) providing evidence on the causal impact of global factors on the intracommodity transmission using linear and nonlinear causality frameworks proposed by Granger [37] and Péguin-Feissolle and Teräsvirta [38].

In application, our results indicate strong bi-directional transmission between oil and metal (agriculture) markets, and this transmission became significantly more pronounced during the turmoil period, i.e., the global financial crisis. Our analysis also suggests that oil 
is a net transmitter to other commodity uncertainties, and this transmission significantly increased during the period of the global financial crisis. Additionally, our results indicate that the global factors in some way have a causal effect on the overall connectedness, especially on the spillovers from oil to other commodity uncertainties. Further segregation of transmissions from oil to individual commodity markets and vice versa indicate the S\&P 500 volatility index (VIX), and to some extent, difference between the interest rate on short-term U.S. government debt and the interest rate on interbank loans (TED) spread and the U.S. economic policy uncertainty index (EPU), as the most influential drivers of connectedness among commodity markets.

The remainder of this paper is divided into five sections. Section 2 provides a review of previous literature. Section 3 outlines the methodology used to analyze the transmission between oil and other commodity uncertainties and examination of the impact of global factors on the transmission across commodity markets. Section 4 provides details of the data and summary statistics. The empirical findings are discussed in Section 5. Finally, Section 6 makes concluding remarks.

\section{Literature Review}

\subsection{Oil and Commodity Markets}

As indicated earlier, the empirical finance literature is rich in studies focusing on the linkage between the precious metals, industrial metals, and agricultural commodities with oil markets (such as [7,19,39-50]). Sari et al. [26] find a short-term relationship between precious metals and crude oil in the context of developed countries. Hammoudeh and Yuan [11] indicate that, in the US metal market, lagged crude oil prices drive univariate volatilities of precious metals like gold, silver, and copper. In the same way, high comovement between gold and crude oil prices under long-term equilibrium is documented by Zhang and Wei [51]. Further, the study of Bildirici and Turkmen [52] found significant long-term association between crude oil prices and precious metals. In accordance with the findings of Kanjilal and Ghosh [31], the study also reported significant long-run influence of crude oil prices on gold and copper returns. Diebold et al. [20] characterize connectedness in 19 key commodity volatilities over the period 2011 to 2016 using high-dimensional generalized vector-autoregressive (VAR) and network analysis. The study finds apparent clustering of commodities into groups, and the energy sector is most important in sending shocks to other commodities. Moreover, there is high connectedness between energy commodities, precious metals, industrial metals, agricultural commodities, and soft commodities. Balli et al. [19] find that connectedness among 22 commodity uncertainty indexes increased during the global financial crisis (GFC) and the oil price collapse of 2014-2016 using spillover analysis. Furthermore, network graphs analysis shows that precious metals may have served as a safe-haven due to less spillover with other commodities during the crisis period. In that regard, the study tests the following hypotheses:

Hypothesis 1a (H1a). There are no spillovers between oil and commodity markets.

Hypothesis $\mathbf{1 b} \mathbf{( H 1 b ) . ~ T h e r e ~ a r e ~ n o ~ s p i l l o v e r s ~ b e t w e e n ~ o i l ~ a n d ~ c o m m o d i t y ~ m a r k e t s ~ d u r i n g ~ c r i - ~}$ sis period.

\subsection{Global Factors and Commodity Markets}

Various studies have witnessed more synchronization in the oil prices movement with commodity returns including precious metals, agricultural commodities, and commodity futures for the current decade due to the increased financialization and inclusion of alternative investments within a portfolio of investors [39,53-56]. The crude oil and commodity market risk and return interactions are profoundly investigated in the earlier studies from both directions (say $[57,58]$ ). However, studies that examine the possible causal effect of different global factors on the connectedness of oil and commodities are 
scarce. Therefore, in this study, we argue that global factors can have direct economy-wide effects that ultimately cascade into financial markets.

The earlier research has shown that lenders react with a conservative approach in government lending practices when an augmented level of uncertainty regarding government economic policies exists and, by consequence, the interest rates increase in the market [59]. Rogoff [60] argues that higher oil consumption countries are less vulnerable to shocks than they were in the past due in part to increased energy efficiency. Bouoiyour et al. [61] explores the dynamic association between oil prices and geopolitical risk (low- and high-risk scenarios). The findings of the study indicate oil prices as a nonlinearswitching phenomenon. Prokopczuk et al. [35] explore the association between volatility of commodity markets and economic and financial uncertainty. They conclude that there is a bidirectional relationship between the volatility of a commodity market with financial and economic uncertainty during a recession period. Ordu-Akkaya and Soytas [62] finds that spillover from stocks to commodities during a period of financialization increased for all commodities. Moreover, one of the underlying reasons for increasing spillover between markets was quantitative easing, including default spread, current factors, or interest rate.

Several other factors have been shown to affect the commodity markets, such as financial stress or TED spread [63], Morgan Stanley Capital International (MSCI) World index, U.S. Dollar (USD) index, and financial stress, among others (say [32,64]). Huang et al. [25] investigate the relationship between US oil prices and the prices of gold, copper, and silver in Chinese market. The findings of the study unveil that the network of oil, silver, and gold prices have significant explanatory power in establishing silver and gold prices in the Chinese commodity market. Accordingly, Jebabli et al. [33] find that shocks to MSCI markets or crude oil had short-term and immediate impacts on food markets during the GFC of 2008-2009. De Boyrie and Pavlova [29] find that an increase in the Chicago Board Options Exchange (CBOE) volatility index (VIX) is related to higher agriculture commodities correlations.

Murray [65] finds evidence of Granger-causality from commodity prices to the geopolitical risk (GPR) index in the years preceding the GFC but not afterward. Liu et al. [66] find that GPR causes fluctuations in the oil market, where results strongly confirm the GARCHMIDAS-GPRS model with serious GPR significantly outperforms the GARCH-MIDAS model in the out-of-sample results.

Robe and Wallen [64] reveal that short-term oil implied volatilities and West Texas Intermediate (WTI)-implied volatility term structure is significantly affected by VIX and the other constraints of oil output such as inflation. The authors' explanation regarding inflation channel suggests that higher oil prices not only imply higher energy and production costs, but also that the phenomena cause an interest rate hike. In addition, the positive impact of EPU on stock-commodity association is reported by Badshah et al. [30]. The effects were more pronounced in the case of energy and industrial metals. In the same way, Kanjilal and Ghosh [31] also report the linkages between oil and gold in two specific ways, either through an inflation channel for oil-importing countries or through a revenue channel for oil exporters. Considering the above literature, we test the following hypotheses:

Hypothesis 2a (H2a). Global factors do not Granger-cause spillovers between oil and commodity markets in a linear setting.

Hypothesis $\mathbf{2 b} \mathbf{\mathbf { b }} \mathbf{H} \mathbf{2} \mathbf{b})$. Global factors do not Granger-cause spillovers between oil and commodity markets in a nonlinear setting.

\section{Methodology}

The empirical analysis of this paper is divided into two parts. First, we follow the connectedness framework of Diebold and Yilmaz [36] to estimate the transmission between oil and other commodity uncertainties. After estimating the transmission measures, we 
then test the impact of global factors on the transmission measures between oil and other commodity uncertainties using linear and nonlinear causality tests.

\subsection{Diebold and Yilmaz Transmission Approach}

We follow the connectedness framework of Diebold and Yilmaz [36] to estimate the different transmission measures built from the forecast-error variance decomposition (FEVD) matrix centered on the generalized vector-autoregressive (VAR) model. Consider an n-variate covariance stationary $\operatorname{VAR}(\mathrm{p})$ model,

$$
x_{t}=\sum_{i=1}^{p} \gamma_{i} x_{t-i}+\epsilon_{t}
$$

where $\epsilon_{t} \sim N(0, \Sigma)$. The moving average component of the VAR process is represented by the following moving average (MA) $(\infty)$ process $x_{t}=\sum_{i=0}^{\infty} \omega_{i} \epsilon_{t-i}$, where $\omega_{i}$ is a $n \times n$ coefficient matrix and calculated recursively using $\omega_{i}=\gamma_{1} \omega_{i-1}+\gamma_{2} \omega_{i-2}+\cdots+\gamma_{p} \omega_{i-p}$, and $\omega_{0}$ represents the identity matrix. Taking help from the MA coefficient, we utilize the generalized FEVD, which permits splitting the $H$-step-ahead forecast error of each variable and attributed to various shocks in the system.

We favor the generalized approach of Koop et al. [67] and Pesaran and Shin [68] to achieve orthogonality since the Cholesky factor depends upon the ordering of the variables. The contribution of variable $j$ to the $H$-step-ahead generalized variance of forecast error of variable $i$ is denoted as $\tau_{i j}(\mathrm{H})$ and computed as:

$$
\tau_{i j}(\mathrm{H})=\frac{\sigma_{j j}^{-1} \sum_{h=0}^{H-1}\left(e_{i}^{\prime} \omega_{h} \sum e_{j}\right)^{2}}{\sum_{h=0}^{H-1}\left(e_{i}^{\prime} \omega_{h} \sum \omega_{h}^{\prime} e_{i}\right)^{2}}
$$

where the $j$ th diagonal component of the standard deviation is represented by $\sigma_{j j}$. $\sum$ represents the covariance matrix of errors. $e_{i}$ has a value 1 for $i$ th component and 0 otherwise. Finally, the coefficient matrix that multiplies $h$-lagged error in the infinite moving-average representation of non-orthogonalized VAR is represented by $\omega_{h}$.

We measure the pairwise directional transmission, $\tau_{i j}(\mathrm{H})$, from $j$ to $i$ as:

$$
\mathrm{T}_{i \leftarrow j}^{H}=\tau_{i j}(\mathrm{H})
$$

The ratio of the off-diagonal sum of rows to the sum of all the elements represents the total directional transmission from others to $i$ as:

$$
\mathrm{T}_{i \leftarrow \bullet}^{H}=\frac{1}{N} \sum_{\substack{j=1 \\ j \neq i}}^{N} \tau_{i j}(\mathrm{H})
$$

Furthermore, the ratio of the off-diagonal sums of columns to the sum of all the elements represents the total directional transmission to others from $j$ as:

$$
\mathrm{T}_{\bullet \leftarrow j}^{H}=\frac{1}{N} \sum_{\substack{i=1 \\ i \neq j}}^{N} \tau_{i j}(\mathrm{H})
$$

Finally, the total system-wide transmission is the ratio of the sum of the from-others (to-others) elements of the variance decomposition matrix to the sum of all its elements:

$$
\mathrm{T}^{H}=\frac{1}{N} \sum_{\substack{i, j=1 \\ i \neq j}}^{N} \tau_{i j}(\mathrm{H})
$$




\subsection{Causality Tests}

In the second part of our analysis, we empirically examine the impact of global factors on the transmission relationship between oil and other commodity uncertainties utilizing the linear and nonlinear causality tests.

\subsubsection{Linear Causality Test}

Based on the vector autoregressive (VAR) framework, we employ the linear causality test following Granger [37]. The test can be expressed as:

$$
\begin{aligned}
& x_{t}=\alpha_{0}+\sum_{i=1}^{n} \alpha_{1 i} x_{t-i}+\sum_{i=1}^{m} \alpha_{2 i} y_{t-i}+\varepsilon_{1 t} \\
& y_{t}=\beta_{0}+\sum_{i=1}^{m} \beta_{1 i} y_{t-i}+\sum_{i=1}^{n} \beta_{2 i} x_{t-i}+\varepsilon_{2 t}
\end{aligned}
$$

where $x_{t}$ and $y_{t}$ represent global factors and transmission between oil and other commodity uncertainties, respectively. $\varepsilon_{1 t}$ and $\varepsilon_{2 t}$ are uncorrelated idiosyncratic terms. The null hypothesis tested using Granger [37] causality test is " $x_{t}$ does not Granger-cause $y_{t}$ ". If the lags of $x_{t}$ can predict $y_{t}$, we can reject the hypothesis and $x_{t}$ "Granger-causes" $y_{t}$.

\subsubsection{Nonlinear Causality Tests}

The pioneering work by Granger [37] paved the way for other researchers to look deeply into the causal relationship between economic and financial time series. PéguinFeissolle and Teräsvirta [38] proposed two nonlinear causality tests: (1) Taylor series approximation and (2) Artificial Neural Network (ANN)-based.

The Taylor series approximation causality test is based on the Taylor expansion of the nonlinear function:

$$
x_{t}=f^{*}\left(x_{t-1}, \ldots, x_{t-q}, y_{t-1}, \ldots, y_{t-n}, \vartheta^{*}\right)+\varepsilon_{t}
$$

where $\vartheta^{*}$ is a vector, $x_{t}$ and $y_{t}$ are weakly stationary series, and $f^{*}$ is an unknown function but assumed to represent the causal relationship between $y_{t}$ and $x_{t}$. Moreover, for every point of the sample (parameter) space $\vartheta^{*} \in \Theta, f^{*}$ has a convergent Taylor expansion. In order to examine the non-causality hypothesis, i.e., $y_{t}$ does not cause $x_{t}$, we have:

$$
x_{t}=f^{*}\left(x_{t-1}, \ldots, x_{t-q}, \vartheta\right)+\varepsilon_{t}
$$

To test Equation (9) against Equation (8), following Péguin-Feissolle and Teräsvirta [38] and later Péguin-Feissolle et al. [69], we linearize $f^{*}$ and increase the function form into a $k$ th order Taylor series around an arbitrary sample space. After the approximation and re-parameterization of $f^{*}$, we obtain:

$$
\begin{gathered}
x_{t}=\theta_{0}+\sum_{j=1}^{q} \theta_{j} x_{t-j}+\sum_{j=1}^{n} \gamma_{j} y_{t-j}+\sum_{j_{1}=1}^{q} \sum_{j_{2}=j_{1}}^{q} \theta_{j_{1} j_{2}} x_{t-j_{1}} x_{t-j_{2}}+\sum_{j_{1}=1}^{q} \sum_{j_{2}=1}^{n} \varphi_{j_{1} j_{2}} x_{t-j_{1}} y_{t-j_{2}}+ \\
\sum_{j_{1}=1}^{n} \sum_{j_{2}=j_{1}}^{n} \gamma_{j_{1} j_{2}} y_{t-j_{1}} y_{t-j_{2}}+\cdots+\sum_{j_{1}-1}^{q} \sum_{j_{2}=j_{1}}^{q} \cdots \sum_{j_{k}=j_{k}-1}^{q} \theta_{j_{1} \ldots j_{k}} x_{t-j_{1}} \cdots x_{t-j_{k}}+\cdots+\theta_{j_{1} j_{2}} x_{t-j_{1}} x_{t-j_{2}}+ \\
\sum_{j_{1}=1}^{n} \sum_{j_{2}=j_{1}}^{n} \cdots \sum_{j_{k}=j_{k}-1}^{n} \gamma_{j_{1} \ldots j_{k}} y_{t-j_{1}} \cdots y_{t-j_{k}}+\varepsilon_{t}^{*}
\end{gathered}
$$

where $\varepsilon_{t}^{*}=\varepsilon_{t}+R_{t}{ }^{(k)}(y, x), R_{t}{ }^{(k)}$ represents the remainder with $n \leq k$ and $q \leq k$.

Péguin-Feissolle and Teräsvirta [38] indicate two possible difficulties related to Equation (10). One being multicollinearity due to large $k, q$, and $n$, and second is the small number of degrees of freedom, due to the rapid increase in the number of regressors with $k$. By replacing some observation matrices with their principal components, we can tackle both problems. Hence, we use the principal components and test the null hypothesis of zero coefficients of principal components, tested as:

$$
\text { General }=\frac{\left(S S R_{0}-S S R_{1}\right) / p^{*}}{S S R_{1} /\left(T-1-2 p^{*}\right)}
$$


where we obtain $S S R_{0}$ and $S S R_{1}$ using the following methods. For $S S R_{0}$, we regress $x_{t}$ on 1 and the first principal components $p^{*}$ of the matrix of lags of $x_{t}$ only, to estimate the residuals $\hat{\varepsilon}_{t}, t=1, \ldots, \mathrm{T}$. The squared residuals are summed to obtain $S S R_{0} . S S R_{1}$ are obtained by regressing $\hat{\varepsilon}_{t}$ on 1 and all the terms of the two principal component matrices. The problem of degree of freedom can be tackled by assuming that the general model is "semi-additive":

$$
x_{t}=f\left(x_{t-1}, \ldots, x_{t-q}, \vartheta_{f}\right)+g\left(y_{t-1}, \ldots, y_{t-n}, \vartheta_{g}\right)+\varepsilon_{t}
$$

where $\vartheta^{\prime}=\left(\vartheta_{f}^{\prime}, \vartheta_{g}^{\prime}\right)^{\prime}$ is the parameter vector. If $g\left(y_{t-1}, \ldots, y_{t-n}, \vartheta_{g}\right)=$ constant, then $y_{t}$ does not cause $x_{t}$. In order to obtain the static called "additive", we linearize both functions into $k$ th order Taylor series.

The artificial neural network causality test uses a logistic function. The approximation of the equation $g\left(y_{t-1}, \ldots, y_{t-n}, \vartheta_{g}\right)$ is obtained using:

$$
\vartheta_{0}+\tilde{\mu}_{t}^{\prime} \alpha+\sum_{j=1}^{p} B_{j} \frac{1}{1+e^{-\gamma_{j}^{\prime} \mu_{t}}}
$$

where $\vartheta_{0} \in R, \mu_{t}=\left(1, \widetilde{\mu}_{t}^{\prime}\right)^{\prime}$ is a $(n+1) \times 1$ vector, $\widetilde{\mu}_{t}=\left(y_{t-1}, \ldots, y_{t-n}\right)^{\prime}, \alpha=\left(\alpha_{1}, \ldots, \alpha_{n}\right)^{\prime}$ are $(n \times 1)$ vectors, and $\gamma_{j}=\left(\gamma_{j 0}, \ldots, \gamma_{j n}\right)^{\prime}$ for $j=1, \ldots, p$, are $(n+1) \times 1$ vectors. The null hypothesis of the test is $\left\{y_{t}\right\}$ does not cause $\left\{x_{t}\right\}$. The estimation of the ANN-based causality test serves as (1) comparative analysis for the Taylor-based nonlinear causality test, and (2) serves as a robustness check. The use of nonlinear causality tests also helps minimize possible estimation errors, since we use the estimated transmission measures. Additionally, we utilize the VAR stability tests to ensure the stationarity of residuals.

\section{Data and Summary Statistics}

In order to estimate the transmission between crude oil and other commodities, we use daily data of commodity uncertainties, namely crude oil WTI (WTI), gold (GLD), silver (SLV), platinum (PLT), palladium (PLD), aluminum (ALM), copper (CPR), zinc (ZNC), lead (LED), nickel (NKL), wheat (WHT), corn (CRN), soybean (SBN), coffee (COF), sugar (SGR), cocoa (COC), and cotton (COT) from January 2007 to December 2016. The sample period of commodity uncertainties developed by Balli et al. [19] covers several periods of uncertainty for commodities, including the GFC. Table 1 reports the descriptive statistics for crude oil WTI and other commodity uncertainty indices.

The summary statistics of uncertainty indices indicate that silver and gold have the highest mean uncertainty along with the highest standard deviation indicating the presence of extreme fluctuations. This can be related to the fact that investors use precious metals, such as gold, as a hedge against the inflationary and monetary policy uncertainty [70]. The results of the Jarque Bera test reject the null of normality for all uncertainty indices. Furthermore, the results of Augmented Dickey-Fuller (ADF) and Phillips-Perron (PP) indicate stationarity in all the uncertainty indices and hence, appropriate for the use of the Diebold-Yilmaz (DY) framework. Following Balli et al. [19], we analyze the uncertainty transmission between crude oil WTI and other commodity uncertainties using log-transformed uncertainty indices.

For our objective to analyze whether global factors impact the transmission between crude oil WTI and other commodity uncertainties, we employ a battery of six potential global factors, widely used in the literature. These include: (1) the U.S. economic policy uncertainty index (EPU) developed by Baker et al. [71], (2) the U.S. geopolitical risk index (GPR) developed by Caldara and Iacoviello [72], (3) the S\&P 500 volatility index (VIX) developed by the Chicago Board Options Exchange (CBOE), (4) MSCI world index (MSCI) as a representative of the world stock market index, (5) TED spread (TED), which is the difference between the yield on 90-day Treasury Bill and London Interbank Offered Rate (LIBOR), and (6) the trade-weighted U.S. Dollar Index (USD). The summary statistics for 
six global factors indicate that EPU, GPR, VIX, and TED are stationary; hence, they are not transformed. Whereas MSCI and USD are transformed using the logarithmic first difference in order to achieve stationarity.

Table 1. Descriptive statistics for commodity uncertainties and global factors.

\begin{tabular}{|c|c|c|c|c|c|c|}
\hline & Abbreviation & Mean & Std. Dev. & JB & ADF & PP \\
\hline Crude oil WTI & WTI & 1.87 & 1.42 & $13,915.90 * * *$ & $-3.66^{* * *}$ & $-4.31^{* * *}$ \\
\hline Gold & GLD & 5.15 & 2.85 & $10,078.38 * * *$ & $-5.47^{* * *}$ & $-5.61^{* * *}$ \\
\hline Silver & SLV & 7.88 & 3.69 & $8085.54 * * *$ & $-5.12^{* * *}$ & $-4.45^{* * *}$ \\
\hline Platinum & PLT & 4.00 & 1.65 & $16,150 \cdot 18^{* * *}$ & $-14.35^{* * *}$ & $-12.29^{* * *}$ \\
\hline Palladium & PLD & 2.41 & 2.59 & $17,149.21$ *** & $-6.37^{* * *}$ & $-5.06^{* * *}$ \\
\hline Aluminum & ALM & 0.63 & 0.94 & $147,332.80 * * *$ & $-6.36^{* * *}$ & $-22.20 * * *$ \\
\hline Copper & CPR & 0.31 & 0.28 & $1,282,594.00 * * *$ & $-5.04 * * *$ & $-8.32 * * *$ \\
\hline Zinc & ZNC & 0.72 & 0.52 & $741,914.00 * * *$ & $-7.49^{* * *}$ & $-14.49^{* * *}$ \\
\hline Lead & LED & 0.66 & 0.51 & $589,331.20 * * *$ & $-14.79 * * *$ & $-15.00^{* * *}$ \\
\hline Nickel & NKL & 0.52 & 0.45 & $1,130,079.00^{* * *}$ & $-14.40^{* * *}$ & $-15.91^{* * *}$ \\
\hline Wheat & WHT & 2.02 & 1.83 & $153,832.00 * * *$ & $-7.20 * * *$ & $-5.58 * * *$ \\
\hline Corn & CRN & 2.42 & 1.69 & $15,834.98^{* * *}$ & $-8.89 * * *$ & $-8.73^{* * *}$ \\
\hline Soybean & SBN & 2.33 & 1.43 & $14,194.39^{* * *}$ & $-9.93 * * *$ & $-9.65^{* * *}$ \\
\hline Coffee & $\mathrm{COF}$ & 0.58 & 0.37 & $302,365.70 * * *$ & $-12.50 * * *$ & $-6.71^{* * *}$ \\
\hline Sugar & SGR & 3.67 & 2.11 & $4089.68^{* * *}$ & $-7.54^{* * *}$ & $-5.07^{* * *}$ \\
\hline Cocoa & $\mathrm{COC}$ & 1.27 & 0.63 & $212,745.00$ *** & $-4.37^{* * *}$ & $-9.40^{* * *}$ \\
\hline Cotton & COT & 4.50 & 2.68 & $12,522.60 * * *$ & $-5.83^{* * *}$ & $-7.52^{* * *}$ \\
\hline US EPU & EPU & 115.3 & 71.04 & $3810.31 * * *$ & $-7.96^{* * *}$ & $-35.98^{* * *}$ \\
\hline US GPR & GPR & 85.19 & 60.89 & $14,001.98^{* * *}$ & $-9.86^{* * *}$ & $-39.30^{* * *}$ \\
\hline VIX & VIX & 21.05 & 9.98 & $6251.38^{* * *}$ & $-2.92 * *$ & $-3.87^{* * *}$ \\
\hline MSCI World & MSCI & 0.004 & 1.15 & $6912.08^{* * *}$ & $-34.90^{* * *}$ & $-43.06^{* * *}$ \\
\hline TED Spread & TED & 0.448 & 0.50 & $36,716.87^{* * *}$ & $-2.97 * *$ & $-3.27^{* *}$ \\
\hline USD index & USD & 0.012 & 0.54 & $444.18^{* * *}$ & $-47.65^{* * *}$ & $-47.65^{* * *}$ \\
\hline
\end{tabular}

Note: The table illustrates descriptive statistics of uncertainty series of Balli et al. (2019). The empirical statistics of Augmented Dickey-Fuller (1979) and the Phillips-Perron (1988) unit root tests are represented by ADF and PP. Whereas, JB represents Jarque-Bera test of normality. ${ }^{* *}$ and ${ }^{* * *}$ denotes rejection of null hypothesis at $5 \%$ and $1 \%$ level of significance.

\section{Empirical Findings}

The empirical findings consist of two sections. First, we employ the DY framework to analyze the transmission between crude oil WTI and other commodities' uncertainties and provide evidence of significant transmission between them. Second, we apply linear and non-linear Granger causality models to analyze the impact of six global factors on the transmission between crude oil WTI and other commodity uncertainties.

\subsection{Transmission between Oil and Other Commodity Uncertainties}

Table 2 reports the transmission estimates between oil and other commodity uncertainties. Panel A and B report the estimates of the DY framework for full-sample and the global financial crisis (GFC). Analyzing Panel A, we find that metals, such as palladium, platinum, copper, aluminum, and lead, are the highest receivers of uncertainty from oil, whereas silver, palladium, and copper are the highest transmitters. Strikingly, most of the metals are the highest transmitters and receivers of uncertainty from oil. These findings indicate the strong bi-directional transmission between oil and metal markets, which are in line with the findings evidenced by Kang et al. [21] and Reboredo and Ugolini [57]. Additionally, we also find significant bi-directional transmission between oil and agricultural commodity uncertainties, consistent with the findings of Ji et al. [73] and Nazlioglu et al. [46]. Although the analysis of overall net spillovers (net spillover all uncertainties) between oil and other commodity uncertainties indicates that oil is mostly a net transmitter, additional examination of net pairwise spillovers between oil and other commodity uncertainties suggests oil is a net receiver from gold, silver, palladium, soybean, and cocoa. Similar to the findings of Albulescu et al. [27] about the heterogeneity in the relationship between oil and commodity currencies, we find additional evidence of heterogeneity in the relationship between oil and other commodities. 
Table 2. Diebold-Yilmaz (DY) spillover results.

\begin{tabular}{|c|c|c|c|c|c|c|}
\hline & $\begin{array}{l}\text { From } \\
\text { WTI }\end{array}$ & $\begin{array}{c}\text { From All } \\
\text { Uncertainties }\end{array}$ & To WTI & $\begin{array}{c}\text { To All } \\
\text { Uncertainties }\end{array}$ & $\begin{array}{c}\text { Net } \\
\text { Spillover WTI }\end{array}$ & $\begin{array}{l}\text { Net Spillover } \\
\text { All } \\
\text { Uncertainties }\end{array}$ \\
\hline \multicolumn{7}{|c|}{ Panel A: Full sample (January 2007 to December 2016) } \\
\hline WTI & 68.767 & 1.952 & 68.767 & 2.128 & 0.000 & 0.176 \\
\hline GLD & 0.901 & 2.333 & 1.343 & 2.694 & -0.441 & 0.361 \\
\hline SLV & 0.854 & 1.361 & 8.237 & 5.198 & -7.383 & 3.836 \\
\hline PLT & 4.743 & 1.843 & 0.324 & 0.651 & 4.419 & -1.192 \\
\hline PLD & 5.214 & 2.105 & 8.292 & 3.081 & -3.078 & 0.976 \\
\hline ALM & 3.117 & 2.110 & 0.067 & 1.541 & 3.049 & -0.568 \\
\hline CPR & 3.825 & 2.249 & 3.674 & 3.847 & 0.151 & 1.598 \\
\hline ZNC & 1.112 & 2.418 & 0.372 & 1.493 & 0.740 & -0.925 \\
\hline LED & 2.947 & 2.830 & 0.270 & 4.167 & 2.677 & 1.337 \\
\hline NKL & 2.040 & 5.801 & 0.783 & 0.409 & 1.257 & -5.391 \\
\hline WHT & 0.660 & 2.084 & 0.628 & 2.459 & 0.032 & 0.375 \\
\hline CRN & 1.528 & 2.590 & 2.389 & 2.518 & -0.860 & -0.072 \\
\hline SBN & 2.275 & 2.430 & 0.645 & 2.035 & 1.630 & -0.395 \\
\hline $\mathrm{COF}$ & 1.259 & 2.429 & 1.116 & 0.914 & 0.144 & -1.514 \\
\hline SGR & 0.731 & 1.699 & 0.246 & 2.490 & 0.486 & 0.791 \\
\hline $\mathrm{COC}$ & 2.088 & 1.784 & 2.742 & 1.987 & -0.654 & 0.204 \\
\hline COT & 0.756 & 1.952 & 0.106 & 2.357 & 0.650 & 0.404 \\
\hline \multicolumn{7}{|c|}{ Panel B: Global financial crisis (GFC) (January 2008-June 2009) } \\
\hline WTI & 51.759 & 3.015 & 51.759 & 3.709 & 0.000 & 0.694 \\
\hline GLD & 0.240 & 2.549 & 0.439 & 2.192 & -0.199 & -0.357 \\
\hline SLV & 0.625 & 2.828 & 1.908 & 2.879 & -1.283 & 0.051 \\
\hline PLT & 6.723 & 3.816 & 0.105 & 1.538 & 6.618 & -2.279 \\
\hline PLD & 4.820 & 2.197 & 7.294 & 3.753 & -2.474 & 1.556 \\
\hline ALM & 5.900 & 2.547 & 0.332 & 1.291 & 5.568 & -1.255 \\
\hline CPR & 0.221 & 2.623 & 0.811 & 2.699 & -0.591 & 0.076 \\
\hline ZNC & 0.281 & 2.099 & 0.190 & 2.118 & 0.091 & 0.019 \\
\hline LED & 0.332 & 3.158 & 0.509 & 4.405 & -0.177 & 1.247 \\
\hline NKL & 0.481 & 4.447 & 1.810 & 3.586 & -1.329 & -0.861 \\
\hline WHT & 24.671 & 3.760 & 6.656 & 2.870 & 18.015 & -0.890 \\
\hline CRN & 4.305 & 3.467 & 4.058 & 2.559 & 0.247 & -0.908 \\
\hline SBN & 5.537 & 2.859 & 3.435 & 2.581 & 2.102 & -0.278 \\
\hline $\mathrm{COF}$ & 1.077 & 2.433 & 6.606 & 3.035 & -5.529 & 0.603 \\
\hline SGR & 0.208 & 1.880 & 0.875 & 1.829 & -0.667 & -0.052 \\
\hline $\mathrm{COC}$ & 2.578 & 2.757 & 9.109 & 6.788 & -6.531 & 4.031 \\
\hline COT & 1.340 & 3.007 & 4.104 & 1.612 & -2.764 & -1.396 \\
\hline
\end{tabular}

Note: The table illustrates the estimates of the contribution to the variance of 100-day forecast error of asset $\mathrm{i}$ due to innovations in asset j. Panel A and B report the spillover results of Diebold and Yilmaz (2014) for full sample and global financial crisis (GFC), respectively.

We further analyze the transmission between oil and other commodity uncertainties during the period of the GFC (from January 2008 until June 2009) in Table 2 Panel B and find a substantial increase in the bi-directional transmission between oil and agricultural commodity uncertainties during this period. These results corroborate the findings of Shahzad et al. [74], who find symmetry in the upside and downside spillover impact between oil and agricultural commodities. We also find a significant increase in the overall net spillovers of oil uncertainty, indicating an increase in the overall transmission from oil to other commodity uncertainties. Using visual aid in Figure 1 provides additional support to the argument of a significant increase in the net spillovers of oil during the GFC period. Although we do not report the overall spillovers, the findings indicate a significant increase in the overall spillovers, implying a more pronounced dependence between oil and other commodities during the GFC. 


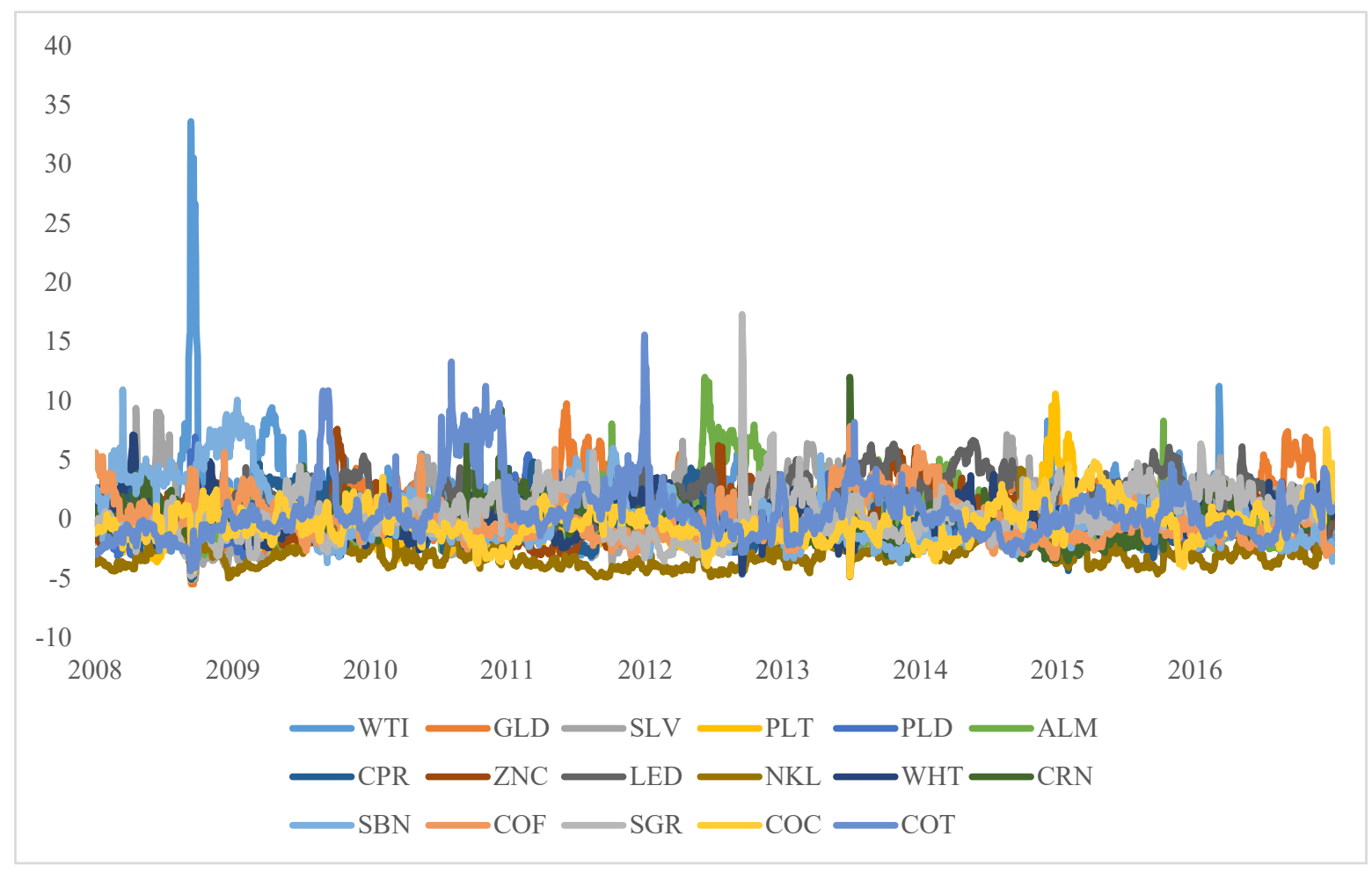

Figure 1. Dynamics of net directional connectedness of oil and other commodity uncertainties.

\subsection{Impact of Global Factors}

In the previous section, we observed bi-directional transmission between oil and other commodity uncertainties, with an increase in the overall transmission during the global financial crisis. Our analysis also points out the role of oil as a net transmitter of uncertainty shocks to the other commodities. In this section, we explore the impact of global factors on the connectedness of commodity markets. Indeed, with the world becoming a global village, stakeholders throughout the world have investments across different markets. Just as markets are open to investment opportunities, they also become prone to the risks associated with globalization, i.e., global liquidity conditions and the risk appetite of investors [27,75], the most notable example being the 2008 sub-prime mortgage crisis, which triggered a global financial meltdown.

We test the impact of global factors on the transmission between oil and other commodity uncertainties using three distinct methods of causality tests, i.e., a linear Grangercausality test proposed by Granger [37], along with two nonlinear (Taylor- and ANN-based) causality tests proposed by Péguin-Feissolle and Teräsvirta [38] and Péguin-Feissolle et al. [69] in Table 3. Panel A and B report the findings for the whole sample and GFC period, respectively. The null hypothesis of global factor does not Granger-cause (a) overall transmission, (b) transmission from oil uncertainty to other commodity uncertainties, and (c) transmission from other commodity uncertainties to oil uncertainty. These are tested. 
Table 3. Linear and nonlinear causality tests for overall and unidirectional spillovers.

\begin{tabular}{|c|c|c|c|c|c|c|c|c|c|c|c|c|}
\hline & \multicolumn{2}{|c|}{ EPU } & \multicolumn{2}{|c|}{ GPR } & \multicolumn{2}{|c|}{ VIX } & \multicolumn{2}{|c|}{ MSCI World } & \multicolumn{2}{|c|}{ TED } & \multicolumn{2}{|c|}{ USD } \\
\hline & Stat & $p$-Value & Stat & $p$-Value & Stat & $p$-Value & Stat & $p$-Value & Stat & $p$-Value & Stat & $p$-Value \\
\hline \multicolumn{13}{|c|}{ Panel A: Full sample (January 2007 to December 2016) } \\
\hline Linear & 3.5477 & 0.4707 & 4.7576 & 0.4462 & 4.5276 & 0.2098 & 0.5812 & 0.7478 & 2.3654 & 0.0509 & 2.5673 & 0.2770 \\
\hline Taylor-based & 1.6579 & 0.1908 & 1.2495 & 0.2869 & 1.2478 & 0.2885 & 2.3481 & 0.0708 & 1.1532 & 0.2830 & 1.6840 & 0.0710 \\
\hline ANN-based & 1.0184 & 0.4159 & 0.7018 & 0.6706 & 0.5621 & 0.7292 & 1.1202 & 0.3478 & 1.0622 & 0.3794 & 1.1660 & 0.3235 \\
\hline \multicolumn{13}{|c|}{ A2: H0: Global factor $-l \rightarrow$ spillover FROM crude oil TO the other markets } \\
\hline Linear & 5.5983 & 0.3473 & 3.8061 & 0.5777 & 5.5512 & 0.0623 & 0.6598 & 0.8826 & 19.7149 & 0.0006 & 9.7011 & 0.0458 \\
\hline Taylor-based & 2.3048 & 0.0986 & 3.7839 & 0.0229 & 59.8155 & 0.0000 & 13.4252 & 0.0000 & 15.7838 & 0.0001 & 39.6647 & 0.0000 \\
\hline ANN-based & 0.2405 & 0.9752 & 1.1624 & 0.3212 & 28.7543 & 0.0000 & 5.3966 & 0.0000 & 46.4748 & 0.0000 & 6.8233 & 0.0000 \\
\hline \multicolumn{13}{|c|}{ A3: H0: Global factor $-I \rightarrow$ spillover FROM other markets TO crude oil } \\
\hline Linear & 9.1587 & 0.0573 & 7.1653 & 0.2086 & 3.0813 & 0.2142 & 1.0881 & 0.5804 & 1.3590 & 0.7152 & 0.4477 & 0.5034 \\
\hline Taylor-based & 2.2803 & 0.0585 & 12.9045 & 0.0000 & 1.8653 & 0.1138 & 0.9563 & 0.4686 & 0.9021 & 0.3423 & 2.2701 & 0.0595 \\
\hline ANN-based & 0.9870 & 0.4388 & 2.3820 & 0.0199 & 0.8297 & 0.5284 & 1.3938 & 0.2132 & 6.6518 & 0.0000 & 3.3619 & 0.0050 \\
\hline \multicolumn{13}{|c|}{ Panel B: Global financial crisis (GFC) (January 2008-June 2009) } \\
\hline Linear & 1.6207 & 0.1841 & 1.3578 & 0.2554 & 1.0625 & 0.3649 & 0.9882 & 0.3208 & 0.0313 & 0.8596 & 0.1472 & 0.7015 \\
\hline Taylor-based & 2.4224 & 0.0905 & 0.5475 & 0.5790 & 0.0825 & 0.7741 & 1.9579 & 0.1628 & 1.4666 & 0.2269 & 1.5912 & 0.2082 \\
\hline ANN-based & 2.7466 & 0.0287 & 1.3996 & 0.2342 & 0.5213 & 0.7202 & 5.3718 & 0.0013 & 5.8258 & 0.0033 & 0.4788 & 0.6201 \\
\hline \multicolumn{13}{|c|}{ B2: H0: Global factor $-I \rightarrow$ spillover FROM crude oil TO the other markets } \\
\hline Linear & 2.3023 & 0.0767 & 1.7942 & 0.1477 & 1.5400 & 0.2037 & 0.4954 & 0.6857 & 2.2322 & 0.1360 & 1.0346 & 0.3772 \\
\hline Taylor-based & 0.4639 & 0.6293 & 0.3813 & 0.6833 & 2.7720 & 0.0970 & 2.9639 & 0.0325 & 28.1361 & 0.0000 & 8.4097 & 0.0000 \\
\hline ANN-based & 1.1195 & 0.3475 & 2.4767 & 0.0445 & 1.1649 & 0.3265 & 0.5222 & 0.7594 & 0.3314 & 0.7182 & 0.5033 & 0.7334 \\
\hline \multicolumn{13}{|c|}{ B3: H0: Global factor $-/ \rightarrow$ spillover FROM other markets TO crude oil } \\
\hline Linear & 0.6159 & 0.4330 & 2.3182 & 0.0998 & 1.2820 & 0.2802 & 3.4551 & 0.0638 & 0.7287 & 0.3938 & 0.3681 & 0.5444 \\
\hline Taylor-based & 0.5880 & 0.4438 & 2.0656 & 0.1286 & 0.4847 & 0.4869 & 2.2490 & 0.1074 & 1.3217 & 0.2515 & 0.0032 & 0.9549 \\
\hline ANN-based & 1.1663 & 0.3130 & 2.2859 & 0.0790 & 2.0375 & 0.0893 & 1.6793 & 0.1716 & 2.3566 & 0.0966 & 0.0016 & 0.9984 \\
\hline
\end{tabular}

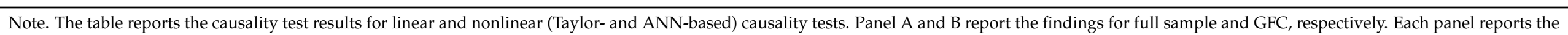

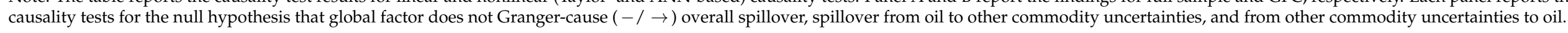


The results from Panel A indicate the impact of MSCI World, TED spread, and USD index on the overall connectedness of oil and other commodity uncertainties. We do not find the impact of EPU, GPR, and VIX on the overall connectedness. Interestingly, the results in sub-panel A2 indicate a substantial impact of the global factors on the transmission from oil to other commodity uncertainties, especially VIX, TED spread, and USD index, where linear and nonlinear tests show consistent evidence of causality. Consequently, we find evidence of the nonlinear causal impact of EPU, GPR, and MSCI World. The evidence from Panel A3 further indicates the bi-directional impact of EPU, GPR, TED spread, and USD index. The above findings provide evidence that nearly all the global factors in some way tend to drive the bi-directional connectedness of commodity markets. The evidence also suggests the intermediary role of oil to transfer the impact of global factors on other commodity markets. The above evidence can be related to the findings provided by Ciner et al. [42], and more recently, by Batten et al. [76] about the feasibility of oil as a hedge against market shocks. Indeed, if oil can be used as a hedge against market shocks, it is safe to assume that oil acts as a buffer against the impact of global factors on other commodity markets.

We further test the impact of global factors on the transmission between oil and individual commodity uncertainties. In Table 4, we present the results of linear and nonlinear causality tests for the spillovers running from oil to other commodity uncertainties for the whole sample. Although we generally find a significant impact of global factors, the results indicate a stronger impact of VIX, TED spread, and USD index on the transmissions running from oil to other commodity uncertainties. Additionally, a comparison of the linear and nonlinear causality tests yields that the relationship between the spillovers and the global factors is mostly nonlinear. In order to provide further insight into the impact of global factors on the transmission from oil to individual commodity uncertainties, we perform a sub-sample analysis during the period of the GFC. We report the results of the causality tests in Table 5. Compared with other global factors, the analysis indicates the significant impact of VIX, and to some extent, the nonlinear impact of TED spread and EPU on the transmission from oil to individual commodity uncertainties during the GFC period.

Finally, we report the results of linear and nonlinear causality tests for the transmissions running from individual commodity uncertainties to oil in Table 6. Comparing the results to Table 4, we find VIX and TED spread as the significant drivers of connectedness from individual commodity uncertainties to oil. We also find the nonlinear impact of the USD index across all commodity markets. Nevertheless, the analysis reported in Table 7 related to the transmission of individual commodity uncertainty to oil during the GFC sub-period points out the importance of VIX, and to a lesser extent, TED spread and EPU, as the drivers to cross-commodity connectedness.

Interestingly, we find a heterogeneous impact of global factors across different commodity markets. Our findings provide further evidence in support of the idea of the "financialization" of commodity markets [75,77] through various channels. First, our analysis of inter-connectedness between oil and other commodity uncertainties provides evidence of the increase in connectedness, especially during the global financial crisis. These findings are consistent with previous literature on the bi-directional inter-connectedness among commodity markets (such as $[19,22,46,73,74])$. Second, the results related to VIX as the most influential driver of transmission between oil and other commodity uncertainties corroborate the findings of Silvennoinen and Thorp [78] and Yoon et al. [79], indicating the importance of the US stock market as the most significant contributor of spillovers across different asset classes. Finally, the relatively significant causal impact of TED spread, and EPU provides support to the evidence provided by Buyuksahin and Robe [80] and Albulescu et al. [27] for financial market stress (TED spread) and US monetary policy (EPU) as the drivers of financial market connectedness. 
Table 4. Linear and nonlinear causality tests for spillovers from oil to individual commodity uncertainties (full sample).

\begin{tabular}{|c|c|c|c|c|c|c|c|c|c|c|c|c|}
\hline & \multicolumn{2}{|c|}{ EPU } & \multicolumn{2}{|c|}{ GPR } & \multicolumn{2}{|c|}{ VIX } & \multicolumn{2}{|c|}{ MSCI World } & \multicolumn{2}{|c|}{ TED } & \multicolumn{2}{|c|}{ USD } \\
\hline & Stat & $p$-Value & Stat & $p$-Value & Stat & $p$-Value & Stat & $p$-Value & Stat & $p$-Value & Stat & $p$-Value \\
\hline \multicolumn{13}{|c|}{ H0: Global factor $-I \rightarrow$ spillover FROM crude oil TO gold } \\
\hline Linear & 0.8710 & 0.4996 & 5.9034 & 0.0000 & 0.4699 & 0.7990 & 2.6677 & 0.0461 & 2.6953 & 0.0444 & 4.2863 & 0.0000 \\
\hline Taylor-based & 1.0077 & 0.3883 & 2.8133 & 0.0602 & 14.7280 & 0.0001 & 2.0662 & 0.0440 & 2.3609 & 0.1245 & 11.8387 & 0.0000 \\
\hline ANN-based & 1.8283 & 0.1206 & 2.4489 & 0.0168 & 14.3010 & 0.0000 & 5.3515 & 0.0000 & 29.6800 & 0.0000 & 1.7658 & 0.1166 \\
\hline \multicolumn{13}{|c|}{ H0: Global factor $-I \rightarrow$ spillover FROM crude oil TO silver } \\
\hline Linear & 0.4969 & 0.7788 & 5.0657 & 0.0001 & 0.5336 & 0.7510 & 17.7453 & 0.0000 & 6.2423 & 0.0003 & 0.3372 & 0.7984 \\
\hline Taylor-based & 1.5600 & 0.2104 & 17.2247 & 0.0000 & 94.1650 & 0.0000 & 4.3676 & 0.0001 & 0.4990 & 0.4800 & 16.5499 & 0.0000 \\
\hline ANN-based & 6.3265 & 0.0000 & 0.6425 & 0.7209 & 43.7637 & 0.0000 & 11.1924 & 0.0000 & 16.2032 & 0.0000 & 9.2562 & 0.0000 \\
\hline \multicolumn{13}{|c|}{ H0: Global factor $-l \rightarrow$ spillover FROM crude oil TO platinum } \\
\hline Linear & 1.9520 & 0.0577 & 1.3830 & 0.1896 & 1.4211 & 0.1918 & 2.0527 & 0.0452 & 0.7224 & 0.6530 & 1.9196 & 0.1045 \\
\hline Taylor-based & 1.7888 & 0.1472 & 51.0005 & 0.0000 & 13.2123 & 0.0003 & 2.3438 & 0.0293 & 24.3331 & 0.0000 & 15.7756 & 0.0000 \\
\hline ANN-based & 0.9138 & 0.4549 & 14.6384 & 0.0000 & 6.7743 & 0.0000 & 1.7125 & 0.1141 & 29.6308 & 0.0000 & 1.9994 & 0.0758 \\
\hline \multicolumn{13}{|c|}{ H0: Global factor $-l \rightarrow$ spillover FROM crude oil TO palladium } \\
\hline Linear & 0.2511 & 0.9091 & 0.3723 & 0.8679 & 1.7082 & 0.1291 & 3.8372 & 0.0093 & 4.5799 & 0.0033 & 7.5449 & 0.0000 \\
\hline ANN-based & 0.3651 & 0.9227 & 1.0353 & 0.4040 & 20.6270 & 0.0224 & 1.4707 & 0.1843 & 15.1390 & 0.0000 & 1.1743 & 0.3193 \\
\hline \multicolumn{13}{|c|}{ H0: Global factor $-l \rightarrow$ spillover FROM crude oil TO aluminum } \\
\hline Linear & 0.2244 & 0.9249 & 1.7043 & 0.1300 & 0.8615 & 0.5061 & 1.1713 & 0.3213 & 1.7553 & 0.1350 & 1.6876 & 0.1501 \\
\hline Taylor-based & 5.8399 & 0.0030 & 7.7639 & 0.0054 & 66.5353 & 0.0000 & 1.9649 & 0.0673 & 4.6179 & 0.0317 & 6.9828 & 0.0000 \\
\hline ANN-based & 11.0410 & 0.0000 & 10.4251 & 0.0000 & 22.0219 & 0.0000 & 6.7283 & 0.0000 & 28.7855 & 0.0000 & 6.7615 & 0.0000 \\
\hline \multicolumn{13}{|c|}{ H0: Global factor $-I \rightarrow$ spillover FROM crude oil TO copper } \\
\hline Linear & 1.3666 & 0.2059 & 0.9077 & 0.5249 & 0.3165 & 0.9287 & 2.7122 & 0.0056 & 1.0560 & 0.3912 & 8.9293 & 0.0000 \\
\hline Taylor-based & 0.1401 & 0.8693 & 1.2701 & 0.2810 & 27.8830 & 0.0000 & 3.0288 & 0.0060 & 17.0333 & 0.0000 & 8.9347 & 0.0000 \\
\hline ANN-based & 0.3411 & 0.9352 & 0.5291 & 0.8131 & 9.7717 & 0.0000 & 3.2895 & 0.0032 & 16.6486 & 0.0000 & 2.4563 & 0.0314 \\
\hline \multicolumn{13}{|c|}{ H0: Global factor $-l \rightarrow$ spillover FROM crude oil TO zinc } \\
\hline Linear & 1.2261 & 0.2939 & 1.5267 & 0.1779 & 0.2293 & 0.9499 & 0.5766 & 0.6796 & 0.4732 & 0.7554 & 0.9708 & 0.4506 \\
\hline Taylor-based & 3.5515 & 0.0288 & 0.0449 & 0.9561 & 21.1715 & 0.0000 & 1.8860 & 0.3667 & 0.0202 & 0.8871 & 8.4231 & 0.0000 \\
\hline ANN-based & 3.8907 & 0.0087 & 0.6393 & 0.6344 & 11.6719 & 0.0000 & 3.4005 & 0.0024 & 28.0229 & 0.0000 & 3.1977 & 0.0070 \\
\hline
\end{tabular}


Table 4. Cont.

\begin{tabular}{|c|c|c|c|c|c|c|c|c|c|c|c|c|}
\hline & \multicolumn{2}{|c|}{ EPU } & \multicolumn{2}{|c|}{ GPR } & \multicolumn{2}{|c|}{ VIX } & \multicolumn{2}{|c|}{ MSCI World } & \multicolumn{2}{|c|}{ TED } & \multicolumn{2}{|c|}{ USD } \\
\hline & Stat & $p$-Value & Stat & $p$-Value & Stat & $p$-Value & Stat & $p$-Value & Stat & $p$-Value & Stat & $p$-Value \\
\hline \multicolumn{13}{|c|}{ H0: Global factor $-I \rightarrow$ spillover FROM crude oil TO lead } \\
\hline Linear & 1.5391 & 0.1381 & 0.9741 & 0.4481 & 1.0533 & 0.3913 & 3.5789 & 0.0008 & 1.2507 & 0.2649 & 9.0142 & 0.0000 \\
\hline Taylor-based & 7.3626 & 0.0007 & 0.1307 & 0.7178 & 13.4060 & 0.0003 & 1.8092 & 0.0935 & 1.3220 & 0.2504 & 0.4673 & 0.9431 \\
\hline ANN-based & 2.7422 & 0.0272 & 1.0137 & 0.3855 & 2.1832 & 0.0535 & 0.6743 & 0.6705 & 25.6573 & 0.0000 & 0.2808 & 0.9238 \\
\hline \multicolumn{13}{|c|}{ H0: Global factor $-/ \rightarrow$ spillover FROM crude oil TO nickel } \\
\hline Linear & 3.1023 & 0.0029 & 1.8810 & 0.0684 & 0.5805 & 0.7724 & 5.5338 & 0.0000 & 2.8659 & 0.0055 & 2.4901 & 0.0414 \\
\hline Taylor-based & 0.4995 & 0.6069 & 2.7478 & 0.0975 & 4.3340 & 0.0017 & 1.7599 & 0.1035 & 0.6584 & 0.4176 & 2.5119 & 0.0015 \\
\hline ANN-based & 0.5692 & 0.6353 & 16.5900 & 0.0000 & 12.4093 & 0.0000 & 6.9391 & 0.0000 & 33.3496 & 0.0000 & 3.4895 & 0.0038 \\
\hline \multicolumn{13}{|c|}{ H0: Global factor $-/ \rightarrow$ spillover FROM crude oil TO wheat } \\
\hline Linear & 0.9868 & 0.4322 & 1.7429 & 0.1069 & 0.1421 & 0.9906 & 0.7651 & 0.5749 & 0.6987 & 0.6244 & 5.4851 & 0.0000 \\
\hline Taylor-based & 3.1870 & 0.0744 & 0.2953 & 0.7443 & 25.0459 & 0.0000 & 0.6512 & 0.6893 & 0.1733 & 0.6772 & 23.5971 & 0.0000 \\
\hline ANN-based & 0.4808 & 0.6183 & 0.7006 & 0.5915 & 15.0613 & 0.0000 & 3.6814 & 0.0012 & 54.6548 & 0.0000 & 8.2629 & 0.0000 \\
\hline \multicolumn{13}{|c|}{ H0: Global factor $-I \rightarrow$ spillover FROM crude oil TO corn } \\
\hline Linear & 1.4560 & 0.2009 & 1.3021 & 0.2599 & 0.4638 & 0.8034 & 0.0887 & 0.7658 & 1.4749 & 0.2289 & 0.9274 & 0.4469 \\
\hline ANN-based & 6.1555 & 0.0004 & 0.3717 & 0.7734 & 8.6047 & 0.0000 & 0.7207 & 0.6329 & 7.8646 & 0.0000 & 6.2589 & 0.0000 \\
\hline \multicolumn{13}{|c|}{ H0: Global factor $-/ \rightarrow$ spillover FROM crude oil TO soybean } \\
\hline Linear & 1.3427 & 0.2343 & 2.0056 & 0.0747 & 4.2398 & 0.0003 & 2.3241 & 0.0304 & 1.2152 & 0.2950 & 2.7128 & 0.0038 \\
\hline Taylor-based & 13.8969 & 0.0000 & 56.4882 & 0.0000 & 16.4555 & 0.0001 & 2.6895 & 0.0297 & 18.4894 & 0.0000 & 8.3412 & 0.0000 \\
\hline ANN-based & 17.6759 & 0.0000 & 28.4296 & 0.0000 & 0.8032 & 0.5473 & 1.2743 & 0.2657 & 16.1131 & 0.0000 & 0.3351 & 0.8919 \\
\hline \multicolumn{13}{|c|}{ H0: Global factor $-I \rightarrow$ spillover FROM crude oil TO coffee } \\
\hline Linear & 1.1418 & 0.3351 & 1.7509 & 0.1052 & 2.0131 & 0.0605 & 1.1059 & 0.3310 & 1.8247 & 0.1211 & 5.8454 & 0.0000 \\
\hline Taylor-based & 0.3265 & 0.7215 & 18.0011 & 0.0000 & 2.7338 & 0.0984 & 13.2656 & 0.0000 & 2.7315 & 0.0985 & 13.0944 & 0.0000 \\
\hline ANN-based & 0.1419 & 0.9349 & 1.3030 & 0.2718 & 1.8020 & 0.1092 & 2.2906 & 0.0330 & 28.7761 & 0.0000 & 4.2095 & 0.0008 \\
\hline \multicolumn{13}{|c|}{ H0: Global factor $-l \rightarrow$ spillover FROM crude oil TO sugar } \\
\hline Linear & 1.4452 & 0.1932 & 0.4330 & 0.6486 & 0.3649 & 0.9015 & 0.1485 & 0.7000 & 1.8081 & 0.1434 & 2.2569 & 0.0210 \\
\hline Taylor-based & 1.0333 & 0.3560 & 7.4875 & 0.0063 & 2.4626 & 0.1167 & 1.4398 & 0.1955 & 17.5637 & 0.0000 & 5.5602 & 0.0000 \\
\hline ANN-based & 0.4111 & 0.7451 & 2.6129 & 0.0497 & 2.0800 & 0.0651 & 0.5306 & 0.7854 & 5.8831 & 0.0000 & 0.9720 & 0.4334 \\
\hline
\end{tabular}


Table 4. Cont

\begin{tabular}{|c|c|c|c|c|c|c|c|c|c|c|c|c|}
\hline & \multicolumn{2}{|c|}{ EPU } & \multicolumn{2}{|c|}{ GPR } & \multicolumn{2}{|c|}{ VIX } & \multicolumn{2}{|c|}{ MSCI World } & \multicolumn{2}{|c|}{ TED } & \multicolumn{2}{|c|}{ USD } \\
\hline & Stat & $p$-Value & Stat & $p$-Value & Stat & $p$-Value & Stat & $p$-Value & Stat & $p$-Value & Stat & $p$-Value \\
\hline \multicolumn{13}{|c|}{ H0: Global factor $-I \rightarrow$ spillover FROM crude oil TO cocoa } \\
\hline Linear & 1.5819 & 0.1762 & 3.6625 & 0.0026 & 2.9011 & 0.0128 & 1.6173 & 0.2035 & 1.5922 & 0.2036 & 5.3742 & 0.0000 \\
\hline Taylor-based & 0.2980 & 0.7423 & 89.8838 & 0.0000 & 12.0045 & 0.0005 & 0.6071 & 0.7249 & 2.2374 & 0.1348 & 8.8683 & 0.0000 \\
\hline ANN-based & 3.2166 & 0.0220 & 21.6909 & 0.0000 & 10.1997 & 0.0000 & 4.7777 & 0.0001 & 13.5966 & 0.0000 & 3.3364 & 0.0053 \\
\hline \multicolumn{13}{|c|}{ H0: Global factor $-I \rightarrow$ spillover FROM crude oil TO cotton } \\
\hline Linear & 2.0676 & 0.0436 & 2.0425 & 0.0464 & 0.6190 & 0.7407 & 2.8635 & 0.0055 & 1.1970 & 0.3006 & 9.9179 & 0.0000 \\
\hline Taylor-based & 5.0514 & 0.0065 & 6.3274 & 0.0120 & 223.8052 & 0.0000 & 8.8553 & 0.0000 & 128.4767 & 0.0000 & 18.7563 & 0.0000 \\
\hline ANN-based & 6.8771 & 0.0001 & 1.4842 & 0.2169 & 94.0210 & 0.0000 & 7.9605 & 0.0000 & 58.8682 & 0.0000 & 7.3980 & 0.0000 \\
\hline
\end{tabular}

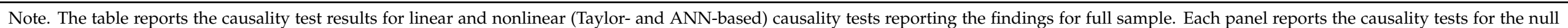
hypothesis that global factor does not Granger-cause $(-/ \rightarrow)$ spillover from oil to individual commodity uncertainties.

Table 5. Linear and nonlinear causality tests for spillovers from oil to individual commodity uncertainties (GFC sub-sample).

\begin{tabular}{|c|c|c|c|c|c|c|c|c|c|c|c|c|}
\hline & \multicolumn{2}{|c|}{ EPU } & \multicolumn{2}{|c|}{ GPR } & \multicolumn{2}{|c|}{ VIX } & \multicolumn{2}{|c|}{ MSCI World } & \multicolumn{2}{|c|}{ TED } & \multicolumn{2}{|c|}{ USD } \\
\hline & Stat & $p$-Value & Stat & $p$-Value & Stat & $p$-Value & Stat & $p$-Value & Stat & $p$-Value & Stat & $p$-Value \\
\hline \multicolumn{13}{|c|}{ H0: Global factor $-I \rightarrow$ spillover FROM crude oil TO gold } \\
\hline Linear & 4.4579 & 0.0354 & 0.0248 & 0.8748 & 1.5567 & 0.2129 & 3.5815 & 0.0592 & 4.9691 & 0.0264 & 0.1937 & 0.6601 \\
\hline Taylor-based & 0.1232 & 0.7258 & 0.3159 & 0.5745 & 2.3378 & 0.1274 & 1.4502 & 0.2295 & 4.7641 & 0.0299 & 0.3339 & 0.7164 \\
\hline ANN-based & 0.2373 & 0.7889 & 0.9207 & 0.3994 & 6.6471 & 0.0015 & 2.0564 & 0.1062 & 4.1544 & 0.0167 & 0.0185 & 0.9817 \\
\hline \multicolumn{13}{|c|}{ H0: Global factor $-I \rightarrow$ spillover FROM crude oil TO silver } \\
\hline Linear & 3.3127 & 0.0695 & 1.0051 & 0.3167 & 0.8032 & 0.3707 & 7.9639 & 0.0050 & 2.0013 & 0.1580 & 0.9704 & 0.3252 \\
\hline Taylor-based & 1.7354 & 0.1888 & 0.2433 & 0.6222 & 0.3360 & 0.5626 & 4.1434 & 0.0427 & 1.9444 & 0.1643 & 2.2424 & 0.1081 \\
\hline ANN-based & 2.1174 & 0.1222 & 0.9729 & 0.3793 & 14.4260 & 0.0000 & 4.7816 & 0.0029 & 3.1676 & 0.0248 & 0.3190 & 0.7271 \\
\hline \multicolumn{13}{|c|}{ H0: Global factor $-I \rightarrow$ spillover FROM crude oil TO platinum } \\
\hline Linear & 1.1630 & 0.2815 & 0.0331 & 0.8558 & 0.9920 & 0.3199 & 5.7417 & 0.0170 & 0.2809 & 0.5964 & 0.9070 & 0.3415 \\
\hline Taylor-based & 0.2885 & 0.5916 & 0.2016 & 0.6538 & 2.0944 & 0.1489 & 0.0770 & 0.7816 & 0.5691 & 0.4513 & 0.5036 & 0.6049 \\
\hline ANN-based & 1.1515 & 0.3176 & 0.6518 & 0.5219 & 3.5038 & 0.0314 & 0.1728 & 0.9147 & 2.9054 & 0.0563 & 0.2601 & 0.7712 \\
\hline
\end{tabular}


Table 5. Cont.

\begin{tabular}{|c|c|c|c|c|c|c|c|c|c|c|c|c|}
\hline & \multicolumn{2}{|c|}{ EPU } & \multicolumn{2}{|c|}{ GPR } & \multicolumn{2}{|c|}{ VIX } & \multicolumn{2}{|c|}{ MSCI World } & \multicolumn{2}{|c|}{ TED } & \multicolumn{2}{|c|}{ USD } \\
\hline & Stat & $p$-Value & Stat & $p$-Value & Stat & $p$-Value & Stat & $p$-Value & Stat & $p$-Value & Stat & $p$-Value \\
\hline \multicolumn{13}{|c|}{ H0: Global factor $-I \rightarrow$ spillover FROM crude oil TO palladium } \\
\hline Linear & 0.0013 & 0.9711 & 4.2638 & 0.0396 & 2.3240 & 0.0993 & 0.7904 & 0.3745 & 1.8784 & 0.1542 & 0.5071 & 0.6027 \\
\hline Taylor-based & 0.6660 & 0.4151 & 5.4104 & 0.0207 & 1.0176 & 0.3139 & 3.5006 & 0.0624 & 0.2558 & 0.6134 & 0.8411 & 0.5000 \\
\hline ANN-based & 0.0749 & 0.9279 & 3.7166 & 0.0255 & 0.6453 & 0.5865 & 1.1465 & 0.3307 & 5.0888 & 0.0019 & 0.8479 & 0.4687 \\
\hline \multicolumn{13}{|c|}{ H0: Global factor $-l \rightarrow$ spillover FROM crude oil TO aluminum } \\
\hline Linear & 1.1744 & 0.3101 & 3.5215 & 0.0305 & 0.8762 & 0.4172 & 0.7334 & 0.4810 & 0.1741 & 0.8403 & 0.4021 & 0.6692 \\
\hline Taylor-based & 0.1152 & 0.8912 & 0.8317 & 0.4364 & 1.0421 & 0.3082 & 0.9555 & 0.3859 & 0.0002 & 0.9894 & 1.1176 & 0.3484 \\
\hline ANN-based & 2.0870 & 0.1021 & 2.0881 & 0.1020 & 3.8217 & 0.0104 & 1.3113 & 0.2659 & 0.3463 & 0.7918 & 1.5545 & 0.2007 \\
\hline \multicolumn{13}{|c|}{ H0: Global factor $-/ \rightarrow$ spillover FROM crude oil TO copper } \\
\hline Linear & 0.1889 & 0.8279 & 0.9894 & 0.3728 & 2.5380 & 0.0803 & 3.3991 & 0.0660 & 0.5871 & 0.5564 & 2.4518 & 0.0875 \\
\hline Taylor-based & 0.2542 & 0.7757 & 0.5865 & 0.5569 & 0.1972 & 0.6573 & 1.2961 & 0.2559 & 1.9775 & 0.1607 & 0.3123 & 0.8696 \\
\hline ANN-based & 1.2786 & 0.2819 & 1.9588 & 0.1204 & 0.8161 & 0.4858 & 1.9088 & 0.1283 & 0.4726 & 0.7016 & 0.2778 & 0.8414 \\
\hline \multicolumn{13}{|c|}{ H0: Global factor $-I \rightarrow$ spillover FROM crude oil TO zinc } \\
\hline Linear & 2.9735 & 0.0523 & 0.7906 & 0.4543 & 2.9779 & 0.0521 & 1.0800 & 0.3406 & 2.0918 & 0.1249 & 0.3088 & 0.7345 \\
\hline ANN-based & 7.7015 & 0.0001 & 1.4391 & 0.2316 & 14.9703 & 0.0000 & 1.0547 & 0.3793 & 15.5111 & 0.0000 & 0.0397 & 0.9894 \\
\hline \multicolumn{13}{|c|}{ H0: Global factor $-I \rightarrow$ spillover FROM crude oil TO lead } \\
\hline Linear & 0.9604 & 0.3837 & 1.8877 & 0.1528 & 2.7977 & 0.0622 & 0.4284 & 0.6519 & 0.5804 & 0.5601 & 0.8206 & 0.4409 \\
\hline Taylor-based & 1.6344 & 0.1969 & 1.1500 & 0.3181 & 20.6166 & 0.0000 & 1.0624 & 0.3470 & 1.3575 & 0.2449 & 0.6314 & 0.5953 \\
\hline ANN-based & 3.0892 & 0.0275 & 1.4262 & 0.2353 & 11.6298 & 0.0000 & 0.1239 & 0.9738 & 2.0109 & 0.1126 & 0.3142 & 0.8151 \\
\hline \multicolumn{13}{|c|}{ H0: Global factor $-I \rightarrow$ spillover FROM crude oil TO nickel } \\
\hline Linear & 0.5950 & 0.5521 & 1.0394 & 0.3547 & 1.0425 & 0.3536 & 1.7596 & 0.1735 & 1.3775 & 0.2534 & 0.1764 & 0.8383 \\
\hline Taylor-based & 0.1266 & 0.8811 & 0.1267 & 0.8810 & 6.9483 & 0.0088 & 1.6785 & 0.1885 & 0.0448 & 0.8326 & 0.1095 & 0.9545 \\
\hline ANN-based & 0.3130 & 0.8160 & 0.2319 & 0.8741 & 2.1721 & 0.0915 & 1.0371 & 0.3883 & 1.4059 & 0.2413 & 1.0813 & 0.3574 \\
\hline \multicolumn{13}{|c|}{ H0: Global factor $-I \rightarrow$ spillover FROM crude oil TO wheat } \\
\hline Linear & 2.1073 & 0.1230 & 0.4236 & 0.6550 & 0.5032 & 0.6803 & 0.1343 & 0.8744 & 1.3753 & 0.2540 & 0.1110 & 0.8950 \\
\hline Taylor-based & 0.1436 & 0.8663 & 0.6182 & 0.5397 & 7.2289 & 0.0076 & 0.6362 & 0.5300 & 7.9758 & 0.0051 & 1.0394 & 0.3947 \\
\hline ANN-based & 0.9423 & 0.4206 & 0.3033 & 0.8230 & 2.1252 & 0.0778 & 0.3164 & 0.8669 & 9.4944 & 0.0000 & 0.3717 & 0.7735 \\
\hline
\end{tabular}


Table 5. Cont.

\begin{tabular}{|c|c|c|c|c|c|c|c|c|c|c|c|c|}
\hline & \multicolumn{2}{|c|}{ EPU } & \multicolumn{2}{|c|}{ GPR } & \multicolumn{2}{|c|}{ VIX } & \multicolumn{2}{|c|}{ MSCI World } & \multicolumn{2}{|c|}{ TED } & \multicolumn{2}{|c|}{ USD } \\
\hline & Stat & $p$-Value & Stat & $p$-Value & Stat & $p$-Value & Stat & $p$-Value & Stat & $p$-Value & Stat & $p$-Value \\
\hline \multicolumn{13}{|c|}{ H0: Global factor $-/ \rightarrow$ spillover FROM crude oil TO corn } \\
\hline Linear & 2.2643 & 0.1053 & 0.7066 & 0.4939 & 1.5678 & 0.2098 & 1.1141 & 0.3293 & 2.8131 & 0.0613 & 1.0090 & 0.3655 \\
\hline Taylor-based & 0.1390 & 0.8703 & 0.0573 & 0.9443 & 3.9452 & 0.0480 & 0.3415 & 0.7110 & 0.1936 & 0.6602 & 1.1388 & 0.3384 \\
\hline ANN-based & 2.3449 & 0.0731 & 0.5699 & 0.6353 & 4.9415 & 0.0023 & 0.2803 & 0.8906 & 6.2476 & 0.0004 & 1.1939 & 0.3123 \\
\hline \multicolumn{13}{|c|}{ H0: Global factor $-I \rightarrow$ spillover FROM crude oil TO soybean } \\
\hline Linear & 2.1177 & 0.1217 & 2.758 & 0.0647 & 2.3294 & 0.0987 & 0.2983 & 0.7423 & 2.1196 & 0.1215 & 1.1597 & 0.3147 \\
\hline Taylor-based & 2.2474 & 0.1075 & 1.7454 & 0.1764 & 25.7614 & 0.0000 & 0.4707 & 0.6251 & 6.3435 & 0.0123 & 1.5713 & 0.1820 \\
\hline ANN-based & 3.8891 & 0.0095 & 2.2871 & 0.0788 & 9.8874 & 0.0000 & 0.4177 & 0.7958 & 4.1339 & 0.0069 & 0.4854 & 0.6927 \\
\hline \multicolumn{13}{|c|}{ H0: Global factor $-/ \rightarrow$ spillover FROM crude oil TO coffee } \\
\hline Linear & 0.5948 & 0.5522 & 1.1347 & 0.3226 & 0.3914 & 0.5319 & 0.2807 & 0.7554 & 3.6825 & 0.0260 & 2.7715 & 0.0638 \\
\hline Taylor-based & 0.1268 & 0.8810 & 0.6092 & 0.5445 & 0.2305 & 0.6316 & 1.0686 & 0.3448 & 14.6356 & 0.0002 & 2.8780 & 0.0232 \\
\hline ANN-based & 0.4277 & 0.7333 & 0.6272 & 0.5980 & 8.5501 & 0.0002 & 0.1777 & 0.9498 & 5.5274 & 0.0011 & 1.2700 & 0.2849 \\
\hline \multicolumn{13}{|c|}{ H0: Global factor $-I \rightarrow$ spillover FROM crude oil TO sugar } \\
\hline ANN-based & 4.7279 & 0.0031 & 1.5323 & 0.2063 & 12.7856 & 0.0000 & 0.2252 & 0.9242 & 9.6734 & 0.0000 & 2.0541 & 0.1065 \\
\hline \multicolumn{13}{|c|}{ H0: Global factor $-I \rightarrow$ spillover FROM crude oil TO cocoa } \\
\hline Linear & 3.8810 & 0.0214 & 2.3738 & 0.0945 & 4.9707 & 0.0074 & 2.6543 & 0.0716 & 6.8363 & 0.0012 & 1.3764 & 0.2537 \\
\hline Taylor-based & 0.2158 & 0.8060 & 6.2279 & 0.0023 & 6.0169 & 0.0148 & 0.1717 & 0.8423 & 1.2591 & 0.2628 & 1.2514 & 0.2853 \\
\hline ANN-based & 0.1607 & 0.9227 & 6.4393 & 0.0003 & 3.1426 & 0.0257 & 0.1923 & 0.9423 & 15.0651 & 0.0000 & 1.4380 & 0.2319 \\
\hline \multicolumn{13}{|c|}{ H0: Global factor $-l \rightarrow$ spillover FROM crude oil TO cotton } \\
\hline Linear & 1.4136 & 0.2445 & 2.3660 & 0.0952 & 0.1440 & 0.8659 & 1.9120 & 0.1492 & 1.4759 & 0.2298 & 0.2480 & 0.7805 \\
\hline Taylor-based & 2.9424 & 0.0543 & 1.3251 & 0.2674 & 14.6169 & 0.0002 & 0.7717 & 0.4632 & 21.7886 & 0.0000 & 1.8506 & 0.1031 \\
\hline ANN-based & 8.6847 & 0.0000 & 1.3205 & 0.2679 & 8.9606 & 0.0000 & 1.0227 & 0.3958 & 10.7312 & 0.0000 & 1.2016 & 0.3095 \\
\hline
\end{tabular}

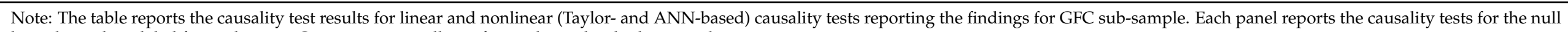
hypothesis that global factor does not Granger-cause spillover from oil to individual commodity uncertainties. 
Table 6. Linear and nonlinear causality tests for spillovers from individual commodity uncertainties to oil (full sample).

\begin{tabular}{|c|c|c|c|c|c|c|c|c|c|c|c|c|}
\hline & \multicolumn{2}{|c|}{ EPU } & \multicolumn{2}{|c|}{ GPR } & \multicolumn{2}{|c|}{ VIX } & \multicolumn{2}{|c|}{ MSCI World } & \multicolumn{2}{|c|}{ TED } & \multicolumn{2}{|c|}{ USD } \\
\hline & Stat & $p$-Value & Stat & $p$-Value & Stat & $p$-Value & Stat & $p$-Value & Stat & $p$-Value & Stat & $p$-Value \\
\hline \multicolumn{13}{|c|}{ H0: Global factor $-l \rightarrow$ spillover FROM gold market TO crude oil } \\
\hline Linear & 2.5463 & 0.0376 & 1.2626 & 0.2771 & 1.2216 & 0.2960 & 1.1192 & 0.3266 & 2.4369 & 0.0875 & 0.4159 & 0.7416 \\
\hline Taylor-based & 3.6286 & 0.0267 & 0.8308 & 0.3621 & 6.4024 & 0.0115 & 0.4488 & 0.8462 & 9.0302 & 0.0027 & 1.0979 & 0.3556 \\
\hline ANN-based & 2.5192 & 0.0564 & 0.4024 & 0.7513 & 2.8510 & 0.0143 & 0.8978 & 0.4955 & 3.9610 & 0.0014 & 0.3678 & 0.8709 \\
\hline \multicolumn{13}{|c|}{ H0: Global factor $-I \rightarrow$ spillover FROM silver TO crude oil } \\
\hline Linear & 0.7789 & 0.5648 & 1.7541 & 0.1188 & 0.6988 & 0.6506 & 0.2830 & 0.5948 & 4.4819 & 0.0114 & 0.3974 & 0.7549 \\
\hline Taylor-based & 2.7037 & 0.0672 & 1.5391 & 0.2149 & 14.6086 & 0.0001 & 0.4105 & 0.8725 & 2.7730 & 0.0960 & 1.6356 & 0.0754 \\
\hline ANN-based & 2.3208 & 0.0734 & 1.9355 & 0.1217 & 7.9589 & 0.0000 & 2.0167 & 0.0602 & 1.4527 & 0.2022 & 2.9420 & 0.0119 \\
\hline \multicolumn{13}{|c|}{ H0: Global factor $-/ \rightarrow$ spillover FROM platinum TO crude oil } \\
\hline Linear & 0.7078 & 0.6175 & 1.4582 & 0.2001 & 1.4059 & 0.2187 & 0.6327 & 0.4264 & 0.3246 & 0.8617 & 0.2408 & 0.9153 \\
\hline Taylor-based & 0.3349 & 0.7154 & 1.4555 & 0.2278 & 2.8752 & 0.0901 & 0.0446 & 0.7756 & 1.7180 & 0.1901 & 0.3453 & 0.9806 \\
\hline ANN-based & 1.0272 & 0.3794 & 2.1926 & 0.0870 & 1.1101 & 0.3528 & 0.5376 & 0.7800 & 2.0508 & 0.0688 & 0.4528 & 0.8115 \\
\hline \multicolumn{13}{|c|}{ H0: Global factor $-/ \rightarrow$ spillover FROM palladium TO crude oil } \\
\hline Linear & 0.7236 & 0.5757 & 3.5128 & 0.0036 & 1.6055 & 0.1550 & 0.5220 & 0.4700 & 0.5014 & 0.4789 & 0.2229 & 0.9695 \\
\hline ANN-based & 1.4444 & 0.2280 & 1.8862 & 0.1298 & 2.9725 & 0.0111 & 1.0107 & 0.4164 & 1.7862 & 0.1123 & 2.3967 & 0.0353 \\
\hline \multicolumn{13}{|c|}{ H0: Global factor $-/ \rightarrow$ spillover FROM aluminum TO crude oil } \\
\hline Linear & 0.5298 & 0.7539 & 0.4175 & 0.8369 & 0.4439 & 0.8180 & 1.3064 & 0.2709 & 1.7434 & 0.1750 & 0.1824 & 0.9084 \\
\hline Taylor-based & 1.8429 & 0.1747 & 0.8167 & 0.3662 & 5.0610 & 0.0246 & 0.5378 & 0.7798 & 5.9429 & 0.0149 & 0.2138 & 0.9986 \\
\hline ANN-based & 0.3483 & 0.7060 & 0.5521 & 0.6467 & 0.6926 & 0.6291 & 0.6287 & 0.7074 & 4.0515 & 0.0012 & 0.7231 & 0.6061 \\
\hline \multicolumn{13}{|c|}{ H0: Global factor $-l \rightarrow$ spillover FROM copper TO crude oil } \\
\hline Linear & 0.8401 & 0.4995 & 0.3255 & 0.8979 & 2.8305 & 0.0148 & 0.9063 & 0.3412 & 0.9703 & 0.3790 & 0.4408 & 0.7238 \\
\hline Taylor-based & 0.0645 & 0.7996 & 3.0005 & 0.0834 & 24.9853 & 0.0000 & 0.0256 & 0.8730 & 11.2288 & 0.0008 & 2.7059 & 0.0670 \\
\hline ANN-based & 5.0885 & 0.0062 & 2.7896 & 0.0617 & 24.1857 & 0.0000 & 2.6963 & 0.0677 & 28.8469 & 0.0000 & 3.0171 & 0.0491 \\
\hline \multicolumn{13}{|c|}{ H0: Global factor $-/ \rightarrow$ spillover FROM zinc TO crude oil } \\
\hline Linear & 0.5857 & 0.7110 & 0.4593 & 0.8067 & 0.2659 & 0.9319 & 0.5594 & 0.5716 & 0.5590 & 0.5718 & 1.9098 & 0.1257 \\
\hline Taylor-based & 0.4094 & 0.5223 & 0.1434 & 0.7050 & 14.7733 & 0.0000 & 0.0001 & 0.9912 & 6.3992 & 0.0115 & 0.9289 & 0.3951 \\
\hline ANN-based & 1.5976 & 0.2026 & 0.1820 & 0.8336 & 11.0464 & 0.0000 & 3.1605 & 0.0426 & 25.4532 & 0.0000 & 1.3158 & 0.2685 \\
\hline
\end{tabular}


Table 6. Cont.

\begin{tabular}{|c|c|c|c|c|c|c|c|c|c|c|c|c|}
\hline & \multicolumn{2}{|c|}{ EPU } & \multicolumn{2}{|c|}{ GPR } & \multicolumn{2}{|c|}{ VIX } & \multicolumn{2}{|c|}{ MSCI World } & \multicolumn{2}{|c|}{ TED } & \multicolumn{2}{|c|}{ USD } \\
\hline & Stat & $p$-Value & Stat & $p$-Value & Stat & $p$-Value & Stat & $p$-Value & Stat & $p$-Value & Stat & $p$-Value \\
\hline \multicolumn{13}{|c|}{ H0: Global factor $-/ \rightarrow$ spillover FROM lead TO crude oil } \\
\hline Linear & 0.3251 & 0.8613 & 0.1421 & 0.9824 & 1.4028 & 0.2400 & 0.2741 & 0.6006 & 0.1933 & 0.8243 & 0.5681 & 0.6360 \\
\hline Taylor-based & 1.0661 & 0.3019 & 2.9192 & 0.0877 & 15.8192 & 0.0001 & 0.8060 & 0.3694 & 2.0017 & 0.1573 & 0.6943 & 0.4995 \\
\hline ANN-based & 1.6191 & 0.1983 & 0.2438 & 0.7836 & 10.7244 & 0.0000 & 2.1816 & 0.1131 & 1.2114 & 0.2980 & 0.9628 & 0.3820 \\
\hline \multicolumn{13}{|c|}{ H0: Global factor $-/ \rightarrow$ spillover FROM nickel TO crude oil } \\
\hline Linear & 0.7725 & 0.5429 & 0.8914 & 0.4858 & 1.6156 & 0.1522 & 1.2158 & 0.2966 & 2.0001 & 0.1354 & 0.4759 & 0.6991 \\
\hline Taylor-based & 0.1222 & 0.7267 & 0.0130 & 0.9094 & 0.1454 & 0.7030 & 1.3066 & 0.2531 & 0.0499 & 0.8233 & 1.1939 & 0.3032 \\
\hline ANN-based & 0.8022 & 0.4485 & 0.4846 & 0.6160 & 7.4321 & 0.0006 & 1.0629 & 0.3456 & 0.2938 & 0.7455 & 1.7040 & 0.1822 \\
\hline \multicolumn{13}{|c|}{ H0: Global factor $-/ \rightarrow$ spillover FROM wheat TO crude oil } \\
\hline Linear & 2.2945 & 0.0570 & 3.9294 & 0.0015 & 1.1774 & 0.3176 & 0.0112 & 0.9159 & 2.0341 & 0.1309 & 0.3019 & 0.8240 \\
\hline Taylor-based & 0.0509 & 0.8215 & 5.1311 & 0.0236 & 0.4847 & 0.4864 & 8.4515 & 0.0000 & 10.1655 & 0.0015 & 2.1873 & 0.0082 \\
\hline ANN-based & 0.9839 & 0.3740 & 5.0694 & 0.0064 & 1.7740 & 0.1699 & 0.8199 & 0.5543 & 9.5223 & 0.0000 & 2.0154 & 0.0735 \\
\hline \multicolumn{13}{|c|}{ H0: Global factor $-I \rightarrow$ spillover FROM corn TO crude oil } \\
\hline Linear & 1.4668 & 0.2095 & 0.4252 & 0.8314 & 0.4319 & 0.8266 & 2.5221 & 0.0804 & 1.0694 & 0.3433 & 0.5874 & 0.6232 \\
\hline ANN-based & 2.8177 & 0.0600 & 0.0336 & 0.9669 & 8.8246 & 0.0002 & 1.8167 & 0.1628 & 5.2883 & 0.0051 & 7.2035 & 0.0008 \\
\hline \multicolumn{13}{|c|}{ H0: Global factor $-/ \rightarrow$ spillover FROM soybean TO crude oil } \\
\hline Linear & 0.1230 & 0.9873 & 2.5602 & 0.0255 & 0.7850 & 0.5603 & 0.0000 & 0.9952 & 0.8804 & 0.3482 & 0.7356 & 0.5306 \\
\hline Taylor-based & 1.4787 & 0.2241 & 4.1616 & 0.0415 & 3.1446 & 0.0763 & 2.0225 & 0.0595 & 0.0921 & 0.7615 & 1.6979 & 0.0551 \\
\hline ANN-based & 0.3691 & 0.6914 & 5.3245 & 0.0012 & 1.8706 & 0.0963 & 2.6492 & 0.0146 & 1.1160 & 0.3496 & 1.8952 & 0.0920 \\
\hline \multicolumn{13}{|c|}{ H0: Global factor $-I \rightarrow$ spillover FROM coffee TO crude oil } \\
\hline Linear & 1.3738 & 0.2403 & 1.0921 & 0.3625 & 0.2994 & 0.9134 & 0.2563 & 0.6127 & 0.1107 & 0.9539 & 1.0771 & 0.3574 \\
\hline Taylor-based & 0.0849 & 0.7708 & 0.3653 & 0.6941 & 2.3349 & 0.1266 & 0.5752 & 0.7504 & 0.0005 & 0.9815 & 0.8890 & 0.5577 \\
\hline ANN-based & 0.1296 & 0.8784 & 0.3762 & 0.9166 & 0.3557 & 0.8788 & 1.4022 & 0.2099 & 1.1146 & 0.3504 & 0.4008 & 0.8485 \\
\hline \multicolumn{13}{|c|}{ H0: Global factor $-/ \rightarrow$ spillover FROM sugar TO crude oil } \\
\hline Linear & 0.5325 & 0.7519 & 0.4831 & 0.7891 & 1.2370 & 0.2888 & 6.1503 & 0.0022 & 0.3019 & 0.7394 & 0.5316 & 0.6606 \\
\hline Taylor-based & 0.5101 & 0.4752 & 1.6402 & 0.2004 & 3.4481 & 0.0081 & 7.9170 & 0.0000 & 11.1397 & 0.0009 & 0.9147 & 0.5368 \\
\hline ANN-based & 0.0966 & 0.9079 & 1.2609 & 0.2836 & 4.1431 & 0.0009 & 4.3244 & 0.0002 & 4.5370 & 0.0004 & 0.1373 & 0.9837 \\
\hline
\end{tabular}


Table 6. Cont

\begin{tabular}{|c|c|c|c|c|c|c|c|c|c|c|c|c|}
\hline & \multicolumn{2}{|c|}{ EPU } & \multicolumn{2}{|c|}{ GPR } & \multicolumn{2}{|c|}{ VIX } & \multicolumn{2}{|c|}{ MSCI World } & \multicolumn{2}{|c|}{ TED } & \multicolumn{2}{|c|}{ USD } \\
\hline & Stat & $p$-Value & Stat & $p$-Value & Stat & $p$-Value & Stat & $p$-Value & Stat & $p$-Value & Stat & $p$-Value \\
\hline \multicolumn{13}{|c|}{ H0: Global factor $-I \rightarrow$ spillover FROM cocoa TO crude oil } \\
\hline Linear & 0.4491 & 0.7732 & 0.2735 & 0.9278 & 0.8575 & 0.5089 & 0.0021 & 0.9636 & 0.5331 & 0.5868 & 0.1782 & 0.9112 \\
\hline Taylor-based & 0.0805 & 0.7766 & 1.2954 & 0.2740 & 13.9516 & 0.0002 & 0.4328 & 0.8574 & 14.1409 & 0.0002 & 2.5138 & 0.0015 \\
\hline ANN-based & 0.1527 & 0.8584 & 0.5708 & 0.7802 & 1.6207 & 0.1511 & 0.9953 & 0.4266 & 14.1446 & 0.0000 & 0.2949 & 0.9159 \\
\hline \multicolumn{13}{|c|}{ H0: Global factor $-I \rightarrow$ spillover FROM cotton TO crude oil } \\
\hline Linear & 1.3833 & 0.2370 & 0.4944 & 0.7807 & 0.8120 & 0.5408 & 4.5693 & 0.0104 & 1.1853 & 0.3057 & 0.3463 & 0.7919 \\
\hline Taylor-based & 0.5274 & 0.4678 & 1.4633 & 0.2265 & 16.7058 & 0.0000 & 4.6880 & 0.0093 & 14.5232 & 0.0001 & 1.3881 & 0.2355 \\
\hline ANN-based & 1.8427 & 0.1586 & 11.0690 & 0.0000 & 7.3390 & 0.0007 & 1.7160 & 0.1616 & 10.8483 & 0.0000 & 1.1197 & 0.3398 \\
\hline
\end{tabular}

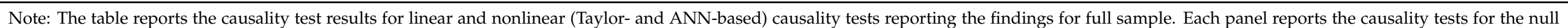

hypothesis that global factor does not Granger-cause spillover from individual commodity to oil uncertainties.

Table 7. Linear and nonlinear causality tests for spillovers from individual commodity uncertainties to oil (GFC sub-sample).

\begin{tabular}{|c|c|c|c|c|c|c|c|c|c|c|c|c|}
\hline & \multicolumn{2}{|c|}{ EPU } & \multicolumn{2}{|c|}{ GPR } & \multicolumn{2}{|c|}{ VIX } & \multicolumn{2}{|c|}{ MSCI World } & \multicolumn{2}{|c|}{ TED } & \multicolumn{2}{|c|}{ USD } \\
\hline & Stat & $p$-Value & Stat & $p$-Value & Stat & $p$-Value & Stat & $p$-Value & Stat & $p$-Value & Stat & $p$-Value \\
\hline \multicolumn{13}{|c|}{ H0: Global factor $-I \rightarrow$ spillover FROM gold TO crude oil } \\
\hline Linear & 6.6873 & 0.0014 & 0.0247 & 0.9756 & 0.2400 & 0.7868 & 1.8050 & 0.1659 & 0.5736 & 0.5640 & 4.8294 & 0.0085 \\
\hline Taylor-based & 0.1286 & 0.8793 & 0.2749 & 0.7599 & 1.6639 & 0.1981 & 0.3293 & 0.7197 & 0.4903 & 0.4844 & 2.6751 & 0.0475 \\
\hline ANN-based & 0.8151 & 0.4864 & 0.2228 & 0.8805 & 0.2954 & 0.8287 & 1.1327 & 0.3413 & 0.4107 & 0.7455 & 2.8753 & 0.0365 \\
\hline \multicolumn{13}{|c|}{ H0: Global factor $-l \rightarrow$ spillover FROM silver TO crude oil } \\
\hline Linear & 2.6290 & 0.1057 & 0.9477 & 0.3309 & 3.3334 & 0.0687 & 0.1356 & 0.8732 & 0.2525 & 0.7770 & 0.3792 & 0.6847 \\
\hline Taylor-based & 0.6202 & 0.4316 & 1.2191 & 0.2705 & 1.9467 & 0.1640 & 0.2889 & 0.7493 & 0.3641 & 0.5467 & 0.2170 & 0.8846 \\
\hline ANN-based & 1.1167 & 0.3288 & 0.4303 & 0.6507 & 1.2893 & 0.2771 & 1.4085 & 0.2312 & 0.1389 & 0.9367 & 0.4174 & 0.7406 \\
\hline \multicolumn{13}{|c|}{ H0: Global factor $-I \rightarrow$ spillover FROM platinum TO crude oil } \\
\hline Linear & 0.3482 & 0.7062 & 1.6547 & 0.1991 & 3.2449 & 0.0724 & 1.2931 & 0.2562 & 0.0294 & 0.8638 & 0.1801 & 0.6715 \\
\hline Taylor-based & 0.3748 & 0.6878 & 0.3281 & 0.5672 & 1.1185 & 0.2911 & 0.0369 & 0.8478 & 0.0492 & 0.8247 & 0.0285 & 0.8660 \\
\hline ANN-based & 0.4594 & 0.7109 & 0.6075 & 0.5454 & 0.9215 & 0.3991 & 1.6897 & 0.1694 & 0.0537 & 0.9478 & 0.1460 & 0.8641 \\
\hline
\end{tabular}


Table 7. Cont.

\begin{tabular}{|c|c|c|c|c|c|c|c|c|c|c|c|c|}
\hline & \multicolumn{2}{|c|}{ EPU } & \multicolumn{2}{|c|}{ GPR } & \multicolumn{2}{|c|}{ VIX } & \multicolumn{2}{|c|}{ MSCI World } & \multicolumn{2}{|c|}{ TED } & \multicolumn{2}{|c|}{ USD } \\
\hline & Stat & $p$-Value & Stat & $p$-Value & Stat & $p$-Value & Stat & $p$-Value & Stat & $p$-Value & Stat & $p$-Value \\
\hline \multicolumn{13}{|c|}{ H0: Global factor $-I \rightarrow$ spillover FROM palladium TO crude oil } \\
\hline Linear & 7.2474 & 0.0074 & 0.3978 & 0.5286 & 1.8911 & 0.1699 & 1.5476 & 0.2142 & 9.9311 & 0.0018 & 0.2689 & 0.6044 \\
\hline Taylor-based & 14.6447 & 0.0002 & 0.3344 & 0.5635 & 1.1237 & 0.2900 & 1.5659 & 0.2118 & 1.8037 & 0.1803 & 0.4062 & 0.5244 \\
\hline ANN-based & 2.8239 & 0.0610 & 2.5265 & 0.0817 & 1.1371 & 0.3222 & 2.3562 & 0.0721 & 3.3952 & 0.0349 & 0.3290 & 0.7199 \\
\hline \multicolumn{13}{|c|}{ H0: Global factor $-l \rightarrow$ spillover FROM aluminum TO crude oil } \\
\hline Linear & 0.1509 & 0.6979 & 0.3782 & 0.5389 & 2.0756 & 0.1505 & 0.1627 & 0.6869 & 0.6246 & 0.4298 & 0.3378 & 0.5614 \\
\hline Taylor-based & 0.3149 & 0.5751 & 0.0935 & 0.7600 & 0.8588 & 0.3548 & 0.0054 & 0.9414 & 0.2392 & 0.6252 & 0.0800 & 0.7775 \\
\hline ANN-based & 0.3807 & 0.6837 & 0.8067 & 0.4474 & 2.3810 & 0.0943 & 1.5627 & 0.1986 & 0.2801 & 0.7559 & 0.2642 & 0.7680 \\
\hline \multicolumn{13}{|c|}{ H0: Global factor $-/ \rightarrow$ spillover FROM copper TO crude oil } \\
\hline Linear & 5.1042 & 0.0244 & 0.2301 & 0.6318 & 10.2814 & 0.0015 & 0.2774 & 0.5987 & 1.6092 & 0.2054 & 0.4268 & 0.5140 \\
\hline Taylor-based & 0.3529 & 0.5530 & 0.4680 & 0.4945 & 2.6273 & 0.1061 & 0.0225 & 0.8809 & 0.6680 & 0.4144 & 0.0332 & 0.8555 \\
\hline ANN-based & 3.9242 & 0.0208 & 0.0975 & 0.9071 & 2.7403 & 0.0662 & 1.3369 & 0.2626 & 0.4576 & 0.6333 & 0.5546 & 0.5749 \\
\hline \multicolumn{13}{|c|}{ H0: Global factor $-I \rightarrow$ spillover FROM zinc TO crude oil } \\
\hline Linear & 0.0289 & 0.8651 & 0.1891 & 0.6639 & 0.6399 & 0.5279 & 0.1286 & 0.8794 & 1.1737 & 0.3103 & 0.4065 & 0.6663 \\
\hline ANN-based & 0.0179 & 0.9822 & 0.0813 & 0.9219 & 0.5549 & 0.6452 & 0.5052 & 0.7319 & 0.9641 & 0.4100 & 0.9860 & 0.3997 \\
\hline \multicolumn{13}{|c|}{ H0: Global factor $-l \rightarrow$ spillover FROM lead TO crude oil } \\
\hline Linear & 2.3690 & 0.0949 & 2.9176 & 0.0553 & 1.8486 & 0.1588 & 0.3329 & 0.7170 & 4.1145 & 0.0171 & 0.6111 & 0.5433 \\
\hline Taylor-based & 1.4634 & 0.2332 & 0.3759 & 0.6870 & 8.2337 & 0.0044 & 0.6839 & 0.5055 & 1.1119 & 0.2925 & 1.9047 & 0.1290 \\
\hline ANN-based & 2.1089 & 0.0993 & 0.8872 & 0.4481 & 3.3878 & 0.0185 & 4.1859 & 0.0026 & 3.9248 & 0.0091 & 1.6112 & 0.1869 \\
\hline \multicolumn{13}{|c|}{ H0: Global factor $-I \rightarrow$ spillover FROM nickel TO crude oil } \\
\hline Linear & 0.2796 & 0.5972 & 0.0959 & 0.7570 & 1.7964 & 0.1673 & 1.2845 & 0.2780 & 0.1098 & 0.8960 & 2.4834 & 0.0848 \\
\hline Taylor-based & 0.0211 & 0.8845 & 6.5693 & 0.0109 & 1.1743 & 0.2794 & 2.4563 & 0.0876 & 0.0201 & 0.8874 & 1.0595 & 0.3667 \\
\hline ANN-based & 0.0313 & 0.9692 & 1.2095 & 0.2999 & 0.4496 & 0.7178 & 1.8882 & 0.1126 & 2.0077 & 0.1130 & 0.6990 & 0.5533 \\
\hline \multicolumn{13}{|c|}{ H0: Global factor $-I \rightarrow$ spillover FROM wheat TO crude oil } \\
\hline Linear & 7.9421 & 0.0004 & 0.1987 & 0.8199 & 3.6339 & 0.0273 & 5.9703 & 0.0028 & 6.7822 & 0.0013 & 1.9061 & 0.1501 \\
\hline Taylor-based & 8.4740 & 0.0003 & 0.1377 & 0.8714 & 21.2606 & 0.0000 & 2.5399 & 0.0807 & 34.8651 & 0.0000 & 5.9021 & 0.0006 \\
\hline ANN-based & 3.7853 & 0.0109 & 0.5091 & 0.6763 & 6.2896 & 0.0004 & 0.8162 & 0.5157 & 14.4067 & 0.0000 & 0.7274 & 0.5364 \\
\hline
\end{tabular}


Table 7. Cont.

\begin{tabular}{|c|c|c|c|c|c|c|c|c|c|c|c|c|}
\hline & \multicolumn{2}{|c|}{ EPU } & \multicolumn{2}{|c|}{ GPR } & \multicolumn{2}{|c|}{ VIX } & \multicolumn{2}{|c|}{ MSCI World } & \multicolumn{2}{|c|}{ TED } & \multicolumn{2}{|c|}{ USD } \\
\hline & Stat & $p$-Value & Stat & $p$-Value & Stat & $p$-Value & Stat & $p$-Value & Stat & $p$-Value & Stat & $p$-Value \\
\hline \multicolumn{13}{|c|}{ H0: Global factor $-I \rightarrow$ spillover FROM corn TO crude oil } \\
\hline Linear & 0.2648 & 0.6071 & 0.5532 & 0.4575 & 2.4653 & 0.1172 & 0.0150 & 0.9851 & 0.4998 & 0.6071 & 1.7389 & 0.1771 \\
\hline Taylor-based & 0.0856 & 0.7700 & 0.0788 & 0.7791 & 1.0193 & 0.3135 & 0.0133 & 0.9869 & 0.2400 & 0.6246 & 0.5134 & 0.6733 \\
\hline ANN-based & 0.4800 & 0.6193 & 0.0079 & 0.9922 & 0.8873 & 0.4129 & 0.5566 & 0.6944 & 0.7599 & 0.5174 & 1.6821 & 0.1710 \\
\hline \multicolumn{13}{|c|}{ H0: Global factor $-I \rightarrow$ spillover FROM soybean TO crude oil } \\
\hline Linear & 0.4129 & 0.5209 & 0.5817 & 0.4461 & 0.6305 & 0.4277 & 0.0245 & 0.8757 & 0.1987 & 0.6560 & 5.4783 & 0.0198 \\
\hline Taylor-based & 0.0214 & 0.8838 & 0.3379 & 0.5615 & 2.0935 & 0.1490 & 0.6002 & 0.4391 & 0.0611 & 0.8049 & 3.1554 & 0.0767 \\
\hline ANN-based & 0.0224 & 0.9778 & 1.4816 & 0.2290 & 3.0569 & 0.0486 & 0.9054 & 0.4389 & 3.6536 & 0.0271 & 2.1741 & 0.1156 \\
\hline \multicolumn{13}{|c|}{ H0: Global factor $-/ \rightarrow$ spillover FROM coffee TO crude oil } \\
\hline Linear & 6.5146 & 0.0111 & 0.2425 & 0.6227 & 1.8421 & 0.1755 & 2.4073 & 0.1216 & 0.2300 & 0.6318 & 0.4226 & 0.5160 \\
\hline Taylor-based & 2.7819 & 0.0965 & 0.1289 & 0.7198 & 2.2772 & 0.1324 & 0.1551 & 0.6940 & 0.0804 & 0.7770 & 0.2366 & 0.6271 \\
\hline ANN-based & 4.6430 & 0.0104 & 0.2977 & 0.7428 & 1.7828 & 0.1700 & 1.5496 & 0.2019 & 1.9644 & 0.1420 & 0.1717 & 0.8423 \\
\hline \multicolumn{13}{|c|}{ H0: Global factor $-l \rightarrow$ spillover FROM sugar TO crude oil } \\
\hline Linear & 0.7557 & 0.3852 & 6.1963 & 0.0132 & 0.8153 & 0.3671 & 6.3019 & 0.0125 & 3.4366 & 0.0645 & 0.6683 & 0.4142 \\
\hline ANN-based & 0.2788 & 0.7569 & 1.6590 & 0.1922 & 1.1815 & 0.3083 & 4.3115 & 0.0054 & 28.5011 & 0.0000 & 0.0586 & 0.9431 \\
\hline \multicolumn{13}{|c|}{ H0: Global factor $-/ \rightarrow$ spillover FROM cocoa TO crude oil } \\
\hline Linear & 0.0727 & 0.7876 & 0.2634 & 0.6081 & 0.0244 & 0.8760 & 0.5758 & 0.4484 & 1.0869 & 0.2978 & 0.7312 & 0.3930 \\
\hline Taylor-based & 0.0964 & 0.7565 & 0.0368 & 0.8480 & 1.4858 & 0.2239 & 0.0778 & 0.7805 & 1.5105 & 0.2201 & 0.0005 & 0.9814 \\
\hline ANN-based & 0.4809 & 0.6187 & 0.0175 & 0.9827 & 1.9466 & 0.1446 & 0.4400 & 0.7245 & 9.2613 & 0.0001 & 1.5288 & 0.2186 \\
\hline \multicolumn{13}{|c|}{ H0: Global factor $-I \rightarrow$ spillover FROM cotton TO crude oil } \\
\hline Linear & 2.2028 & 0.1386 & 1.1079 & 0.2932 & 4.7976 & 0.0291 & 0.3255 & 0.5686 & 1.1729 & 0.2795 & 1.0565 & 0.3047 \\
\hline Taylor-based & 0.2793 & 0.5976 & 0.2568 & 0.6127 & 1.6092 & 0.2056 & 0.0048 & 0.9451 & 0.4275 & 0.5138 & 0.0003 & 0.9869 \\
\hline ANN-based & 0.8714 & 0.4195 & 0.5370 & 0.5851 & 1.6214 & 0.1994 & 1.0831 & 0.3566 & 0.4615 & 0.6308 & 0.2908 & 0.7479 \\
\hline
\end{tabular}

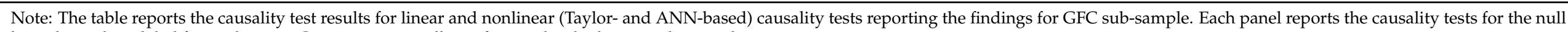
hypothesis that global factor does not Granger-cause spillover from individual commodity to oil uncertainties. 


\section{Conclusions}

In this study, we investigate the impact of global factors on the connectedness of commodity uncertainties from January 2007-December 2016. To this end, we first employ the methodology proposed by Diebold and Yilmaz [36] to estimate the transmission between oil and other commodity uncertainties. Moreover, we make use of the linear and nonlinear (Taylor- and ANN-based) causality tests to estimate the impact of global factors on the connectedness of commodity uncertainties. Performing additional sub-sample analysis, during the global financial crisis, helps us obtain an in-depth insight into the relationship among commodity markets and their interaction with the global factors.

In our study, we find strong bi-directional transmission between oil and metal (agriculture) markets, and this transmission became significantly more pronounced during the turmoil period, i.e., the GFC. Our analysis suggests that oil is a net transmitter to other commodity uncertainties, and this transmission of oil significantly increased during the period of the GFC (2008-2009), which originated as the sub-prime mortgage crisis in the U.S. and consequently resulted in the meltdown of financial markets globally. Additionally, our results indicate that the global factors in some way have a causal effect on the overall connectedness, especially on the spillovers from oil to other commodity uncertainties. Further segregation of transmissions from oil to other commodity markets and vice versa indicate VIX, and to some extent, TED spread and EPU, as the most influential drivers of connectedness among commodity markets.

Amidst the "financialization" of commodities, resulting in a sharp upsurge in the connectedness of commodity markets and their interaction with other financial and macroeconomic determinants, we find that the price of commodities is not only dependent on the supply and demand channel but also determined by the risk appetite of stakeholders. Thus, investors can be watchful of the global factors, such as VIX, which is considered as a proxy for investor sentiment and risk aversion [81] and also regarded as a good predictor of commodity and equity markets $[82,83]$ to better forecast the price changes in commodity markets. Additionally, investors in the commodity market can utilize the insights from our analysis to formulate better portfolio diversification and hedging strategies. In this way, they would be better placed to get through the environment of high-contagion risk. Additionally, policymakers and regulators should carefully assess the risk associated with financial stress and economic policy. This way, they would be able to provide better avenues of risk-sharing for the producers and will be able to incentivize the commodity markets to provide relief to the consumers against the inflationary effects.

Among the limitations of our analysis is that it only uses Diebold and Yilmaz [36] time-domain approach to estimate total static connectedness. A possible direction for future research can be the further segregation of total connectedness into frequencies (i.e., short-, medium-, and long-term). This would provide a more in-depth insight into the causal impact of global factors on different frequency scales. In addition, although the static analysis effectively unveils the structure of connectedness spillovers among commodities, still, time-varying analysis of spillover patterns would also add important insights; hence, the future research can look into this matter.

Author Contributions: Conceptualization, M.A.N.; methodology, M.A.N. and S.F.; software, M.A.N.; validation, M.A.N. and S.F.; formal analysis, M.A.N. and S.F.; investigation, M.A.N. and S.F.; resources, S.M.N. and S.J.H.S.; data curation, M.A.N.; writing—original draft preparation, M.A.N., and S.F.; writing-review and editing, S.M.N. and S.J.H.S.; visualization, M.A.N. and S.J.H.S.; supervision, S.J.H.S.; funding acquisition, S.M.N. All authors have read and agreed to the published version of the manuscript.

Funding: The APC was funded by RHB Islamic Endowed Scholar in Finance research grant (vote: 53276). The authors are grateful to RHB Islamic Bank Berhad for the financial support. M.A.N. also gratefully acknowledges the support of Science Foundation Ireland (grant number: 16/SPP/3347).

Institutional Review Board Statement: Not applicable.

Informed Consent Statement: Not applicable. 
Data Availability Statement: Data was obtained from Thomson Reuters Datastream International and are available from the authors on request.

Conflicts of Interest: The authors declare no conflict of interest. The funders had no role in the design of the study; in the collection, analyses, or interpretation of data; in the writing of the manuscript, or in the decision to publish the results.

\section{References}

1. Aloui, R.; Aïssa, M.S.B.; Nguyen, D.K. Global financial crisis, extreme interdependences, and contagion effects: The role of economic structure? J. Bank. Financ. 2011, 35, 130-141. [CrossRef]

2. Cheng, I.H.; Xiong, W. Financialization of commodity markets. Annu. Rev. Financ. Econ. 2014, 6, 419-441. [CrossRef]

3. Mensi, W.; Beljid, M.; Boubaker, A.; Managi, S. Correlations and volatility spillovers across commodity and stock markets: Linking energies, food, and gold. Econ. Model. 2013, 32, 15-22. [CrossRef]

4. Shahzad, S.J.H.; Raza, N.; Roubaud, D.; Hernandez, J.A.; Bekiros, S. Gold as safe haven for G-7 stocks and bonds: A Revisit. J. Quant. Econ. 2019, 17, 885-912. [CrossRef]

5. Rehman, M.U.; Shahzad, S.J.H.; Uddin, G.S.; Hedström, A. Precious metal returns and oil shocks: A time varying connectedness approach. Resour. Policy 2018, 58, 77-89. [CrossRef]

6. Shahzad, S.J.H.; Naifar, N.; Hammoudeh, S.; Roubaud, D. Directional predictability from oil market uncertainty to sovereign credit spreads of oil-exporting countries: Evidence from rolling windows and crossquantilogram analysis. Energy Econ. 2017, 68, 327-339. [CrossRef]

7. Baumeister, C.; Kilian, L. Do oil price increases cause higher food prices? Econ. Policy 2014, 29, 691-747. [CrossRef]

8. Malik, F.; Umar, Z. Dynamic connectedness of oil price shocks and exchange rates. Energy Econ. 2019, 84, 104501. [CrossRef]

9. Jain, A.; Ghosh, S. Dynamics of global oil prices, exchange rate and precious metal prices in India. Resour. Policy $2013,38,88-93$. [CrossRef]

10. Hooker, M.A. Are oil shocks inflationary? Asymmetric and nonlinear specifications versus changes in regime. J. Money Credit Bank. 2002, 34, 540-561. [CrossRef]

11. Hammoudeh, S.; Yuan, Y. Metal volatility in presence of oil and interest rate shocks. Energy Econ. 2008, 30, 606-620. [CrossRef]

12. Shahzad, S.J.H.; Raza, N.; Balcilar, M.; Ali, S.; Shahbaz, M. Can economic policy uncertainty and investors sentiment predict commodities returns and volatility? Resour. Policy 2017, 53, 208-218. [CrossRef]

13. Pal, D.; Mitra, S.K. Time-frequency contained co-movement of crude oil and world food prices: A wavelet-based analysis. Energy Econ. 2017, 62, 230-239. [CrossRef]

14. Lucotte, Y. Co-movements between crude oil and food prices: A post-commodity boom perspective. Econ. Lett. 2016, 147, 142-147. [CrossRef]

15. Nazlioglu, S. World oil and agricultural commodity prices: Evidence from nonlinear causality. Energy Policy 2011, 39, $2935-2943$. [CrossRef]

16. Pal, D.; Mitra, S.K. Interdependence between crude oil and world food prices: A detrended cross-correlation analysis. Phys. A Stat. Mech. Appl. 2018, 492, 1032-1044. [CrossRef]

17. Zhang, C.; Qu, X. The effect of global oil price shocks on China's agricultural commodities. Energy Econ. 2015, 51, 354-364. [CrossRef]

18. Ahmadi, M.; Behmiri, N.B.; Manera, M. How is volatility in commodity markets linked to oil price shocks? Energy Econ. 2016, 59, 11-23. [CrossRef]

19. Balli, F.; Naeem, M.A.; Shahzad, S.J.H.; De Bruin, A. Spillover network of commodity uncertainties. Energy Econ. 2019, 81, 914-927. [CrossRef]

20. Diebold, F.X.; Liu, L.; Yilmaz, K. Commodity Connectedness; NBER Working Paper No. 23685; National Bureau of Economic Research: Cambridge, MA, USA, 2017.

21. Kang, S.H.; McIver, R.; Yoon, S.M. Dynamic spillover effects among crude oil, precious metal, and agricultural commodity futures markets. Energy Econ. 2017, 62, 19-32. [CrossRef]

22. Kang, S.H.; Tiwari, A.K.; Albulescu, C.T.; Yoon, S.M. Exploring the time-frequency connectedness and network among crude oil and agriculture commodities V1. Energy Econ. 2019, 84, 104543. [CrossRef]

23. Tiwari, A.K.; Nasreen, S.; Shahbaz, M.; Hammoudeh, S. Time-frequency causality and connectedness between international prices of energy, food, industry, agriculture and metals. Energy Econ. 2019, 85, 104529. [CrossRef]

24. Umar, Z.; Nasreen, S.; Solarin, S.A.; Tiwari, A.K. Exploring the time and frequency domain connectedness of oil prices and metal prices. Resour. Policy 2019, 64, 101516. [CrossRef]

25. Huang, X.; An, H.; Gao, X.; Hao, X.; Liu, P. Multiresolution transmission of the correlation modes between bivariate time series based on complex network theory. Phys. A Stat. Mech. Appl. 2015, 428, 493-506. [CrossRef]

26. Sari, R.; Hammoudeh, S.; Ewing, B.T. Dynamic relationships between oil and metal commodity futures prices. Geopolit. Energy 2007, 29, 2-13.

27. Albulescu, C.T.; Demirer, R.; Raheem, I.D.; Tiwari, A.K. Does the US economic policy uncertainty connect financial markets? Evidence from oil and commodity currencies. Energy Econ. 2019, 83, 375-388. [CrossRef] 
28. Fang, L.; Chen, B.; Yu, H.; Xiong, C. The effect of economic policy uncertainty on the long-run correlation between crude oil and the US stock markets. Financ. Res. Lett. 2018, 24, 56-63. [CrossRef]

29. De Boyrie, M.E.; Pavlova, I. Equities and commodities comovements: Evidence from emerging markets. Glob. Econ. J. 2018, 18, 20170075. [CrossRef]

30. Badshah, I.; Demirer, R.; Suleman, T. The effect of economic policy uncertainty on stock-commodity correlations and its implications on optimal hedging. Energy Econ. 2019, 84, 104553. [CrossRef]

31. Kanjilal, K.; Ghosh, S. Dynamics of crude oil and gold price post 2008 global financial crisis-New evidence from threshold vector error-correction model. Resour. Policy 2017, 52, 358-365. [CrossRef]

32. Poncela, P.; Senra, E.; Sierra, L.P. Common dynamics of nonenergy commodity prices and their relation to uncertainty. Appl. Econ. 2014, 46, 3724-3735. [CrossRef]

33. Jebabli, I.; Arouri, M.; Teulon, F. On the effects of world stock market and oil price shocks on food prices: An empirical investigation based on TVP-VAR models with stochastic volatility. Energy Econ. 2014, 45, 66-98. [CrossRef]

34. Batten, J.A.; Szilagyi, P.G.; Wagner, N.F. Should emerging market investors buy commodities? Appl. Econ. 2015, 47, 4228-4246. [CrossRef]

35. Prokopczuk, M.; Stancu, A.; Symeonidis, L. The economic drivers of commodity market volatility. J. Int. Money Financ. 2019, 98, 102063. [CrossRef]

36. Diebold, F.X.; Y1lmaz, K. On the network topology of variance decompositions: Measuring the connectedness of financial firms. J. Econom. 2014, 182, 119-134. [CrossRef]

37. Granger, C.W. Investigating causal relations by econometric models and cross-spectral methods. Econom. J. Econom. Soc. 1969, 37, 424-438. [CrossRef]

38. Péguin-Feissolle, A.; Teräsvirta, T. A General Framework for Testing the Granger Noncausality Hypothesis; SSE/EFI Working Paper Series in Economics and Finance No. 343; Stockholm School of Economics: Stockholm, Sweden, 1999.

39. Ahmadi, M.; Manera, M.; Sadeghzadeh, M. Global oil market and the US stock returns. Energy 2016, 114, 1277-1287. [CrossRef]

40. Campiche, J.L.; Bryant, H.L.; Richardson, J.W.; Outlaw, J.L. Examining the evolving correspondence between petroleum prices and agricultural commodity prices. In American Agricultural Economics Association Annual Meeting, Portland, OR, USA, 29 July-1 August; American Agricultural Economics Association: Austin, TX, USA, 2007.

41. Cha, K.S.; Bae, J.H. Dynamic impacts of high oil prices on the bioethanol and feedstock markets. Energy Policy 2011, 39, 753-760. [CrossRef]

42. Ciner, C.; Gurdgiev, C.; Lucey, B.M. Hedges and safe havens: An examination of stocks, bonds, gold, oil and exchange rates. Int Rev. Financ. Anal. 2013, 29, 202-211. [CrossRef]

43. Hammoudeh, S.M.; Yuan, Y.; McAleer, M. Shock and volatility spillovers among equity sectors of the Gulf Arab stock markets. $Q$. Rev. Econ. Financ. 2009, 49, 829-842. [CrossRef]

44. Juvenal, L.; Petrella, I. Speculation in the oil market. J. Appl. Econom. 2015, 30, 621-649. [CrossRef]

45. Kristoufek, L.; Janda, K.; Zilberman, D. Correlations between biofuels and related commodities before and during the food crisis: A taxonomy perspective. Energy Econ. 2012, 34, 1380-1391. [CrossRef]

46. Nazlioglu, S.; Erdem, C.; Soytas, U. Volatility spillover between oil and agricultural commodity markets. Energy Econ. 2013, 36, 658-665. [CrossRef]

47. Zhang, D.; Broadstock, D.C. Global financial crisis and rising connectedness in the international commodity markets. Int. Rev. Financ. Anal. 2020, 68, 101239. [CrossRef]

48. Youssef, M. Do oil prices and financial indicators drive the herding behavior in commodity markets? J. Behav. Financ. 2020, 1-5. [CrossRef]

49. Rehman, M.U.; Vo, X.V. Energy commodities, precious metals and industrial metal markets: A nexus across different investment horizons and market conditions. Resour. Policy 2021, 70, 101843. [CrossRef]

50. Dutta, A.; Bouri, E.; Roubaud, D. Nonlinear relationships amongst the implied volatilities of crude oil and precious metals. Resour. Policy 2019, 61, 473-478. [CrossRef]

51. Zhang, Y.J.; Wei, Y.M. The crude oil market and the gold market: Evidence for cointegration, causality and price discovery. Resour. Policy 2010, 35, 168-177. [CrossRef]

52. Bildirici, M.E.; Turkmen, C. Nonlinear causality between oil and precious metals. Resour. Policy 2015, 46, 202-211. [CrossRef]

53. Aloui, R.; Gupta, R.; Miller, S.M. Uncertainty and crude oil returns. Energy Econ. 2016, 55, 92-100. [CrossRef]

54. Degiannakis, S.; Filis, G.; Panagiotakopoulou, S. Oil price shocks and uncertainty: How stable is their relationship over time? Econ. Model. 2018, 72, 42-53. [CrossRef]

55. Pastor, L.; Veronesi, P. Uncertainty about government policy and stock prices. J. Financ. 2012, 67, 1219-1264. [CrossRef]

56. Sari, R.; Uzunkaya, M.; Hammoudeh, S. The relationship between disaggregated country risk ratings and stock market movements: An ARDL approach. Emerg. Mark. Financ. Trade 2013, 49, 4-16. [CrossRef]

57. Reboredo, J.C.; Ugolini, A. The impact of downward/upward oil price movements on metal prices. Resour. Policy 2016, 49, 129-141. [CrossRef]

58. Wang, Y.; $\mathrm{Wu}, \mathrm{C}$. Forecasting energy market volatility using GARCH models: Can multivariate models beat univariate models? Energy Econ. 2012, 34, 2167-2181. [CrossRef] 
59. Handley, K.; Limao, N. Trade and investment under policy uncertainty: Theory and firm evidence. Am. Econ. J. Econ. Policy 2015, 7, 189-222. [CrossRef]

60. Rogoff, K. Oil and the Global Economy; Manuscript; Harvard University: Cambridge, MA, USA, 2006; pp. 1-46.

61. Bouoiyour, J.; Selmi, R.; Hammoudeh, S.; Wohar, M.E. What are the categories of geopolitical risks that could drive oil prices higher? Acts or threats? Energy Econ. 2019, 84, 104523. [CrossRef]

62. Ordu-Akkaya, B.M.; Soytas, U. Unconventional monetary policy and financialization of commodities. N. Am. J. Econ. Financ. 2018, 51, 100902. [CrossRef]

63. Büyükşahin, B.; Robe, M.A. Speculators, commodities and cross-market linkages. J. Int. Money Financ. 2014, 42, 38-70. [CrossRef]

64. Robe, M.A.; Wallen, J. Fundamentals, derivatives market information and oil price volatility. J. Futures Mark. 2016, 36, 317-344. [CrossRef]

65. Murray, D. Geopolitical Risk and Commodities: An Investigation. Glob. Commod. Appl. Res. Dig. 2018, 3, 95-106.

66. Liu, J.; Ma, F.; Tang, Y.; Zhang, Y. Geopolitical risk and oil volatility: A new insight. Energy Econ. 2019, 84, 104548. [CrossRef]

67. Koop, G.; Pesaran, M.H.; Potter, S.M. Impulse response analysis in nonlinear multivariate models. J. Econom. 1996, 74, 119-147. [CrossRef]

68. Pesaran, H.H.; Shin, Y. Generalized impulse response analysis in linear multivariate models. Econ. Lett. 1998, 58, 17-29. [CrossRef]

69. Péguin-Feissolle, A.; Strikholm, B.; Teräsvirta, T. Testing the Granger noncausality hypothesis in stationary nonlinear models of unknown functional form. Commun. Stat. Simul. Comput. 2013, 42, 1063-1087. [CrossRef]

70. Bams, D.; Blanchard, G.; Honarvar, I.; Lehnert, T. Does oil and gold price uncertainty matter for the stock market? J. Empir. Financ. 2017, 44, 270-285. [CrossRef]

71. Baker, S.R.; Bloom, N.; Davis, S.J. Measuring economic policy uncertainty. Q. J. Econ. 2016, 131, 1593-1636. [CrossRef]

72. Caldara, D.; Iacoviello, M. Measuring geopolitical risk. In International Finance Discussion Papers 1222; Board of Governors of the Federal Reserve System: Washington, DC, USA, 2018; pp. 1-47.

73. Ji, Q.; Bouri, E.; Roubaud, D.; Shahzad, S.J.H. Risk spillover between energy and agricultural commodity markets: A dependenceswitching CoVaR-copula model. Energy Econ. 2018, 75, 14-27. [CrossRef]

74. Shahzad, S.J.H.; Hernandez, J.A.; Al-Yahyaee, K.H.; Jammazi, R. Asymmetric risk spillovers between oil and agricultural commodities. Energy Policy 2018, 118, 182-198. [CrossRef]

75. Tang, K.; Xiong, W. Index investment and the financialization of commodities. Financ. Anal. J. 2012, 68, 54-74. [CrossRef]

76. Batten, J.A.; Kinateder, H.; Szilagyi, P.G.; Wagner, N.F. Hedging stocks with oil. Energy Econ. 2019, 93, 104422. [CrossRef]

77. Aboura, S.; Chevallier, J. Volatility returns with vengeance: Financial markets vs. commodities. Res. Int. Bus. Financ. 2015, 33, 334-354. [CrossRef]

78. Silvennoinen, A.; Thorp, S. Financialization, crisis and commodity correlation dynamics. J. Int. Financ. Mark. Inst. Money 2013, 24, 42-65. [CrossRef]

79. Yoon, S.M.; Al Mamun, M.; Uddin, G.S.; Kang, S.H. Network connectedness and net spillover between financial and commodity markets. N. Am. J. Econ. Financ. 2019, 48, 801-818. [CrossRef]

80. Buyuksahin, B.; Robe, M.A. Does 'Paper Oil' Matter? Energy Markets' Financialization and Equity-Commodity Co-Movements. Energy Markets' Financialization and Equity-Commodity Co-Movements. 2011. Available online: https://ssrn.com/abstract=18 55264 (accessed on 10 July 2020).

81. Bekaert, G.; Harvey, C.R.; Lundblad, C.T.; Siegel, S. What segments equity markets? Rev. Financ. Stud. 2011, 24, 3841-3890. [CrossRef]

82. Cheng, I.H.; Kirilenko, A.; Xiong, W. Convective risk flows in commodity futures markets. Rev. Financ. 2014, $19,1733-1781$. [CrossRef]

83. Coudert, V.; Gex, M. Does risk aversion drive financial crises? Testing the predictive power of empirical indicators. J. Empir. Financ. 2008, 15, 167-184. [CrossRef] 